\title{
The Bjerkreim-Sokndal Layered Intrusion, Southwest Norway
}

\author{
J.R. Wilson ${ }^{\mathrm{a}}$, B. Robins ${ }^{\mathrm{b}}$, F.M. Nielsen ${ }^{\mathrm{a}}$, J.C. Duchesne ${ }^{\mathrm{c}}$ and J. Vander Auwera ${ }^{\mathrm{c}}$. \\ a. Department of Geology, University of Aarhus, 8000 Aarhus C, Denmark. \\ b. Department of Geology, Allegt. 41, University of Bergen, 5007 Bergen, Norway. \\ c. Laboratoires associés de Géologie, Pétrologie et Géochimie, Université de Liège, B-4000 Sart Tilman, \\ Belgium.
}

\begin{abstract}
The Bjerkreim-Sokndal Layered Intrusion is a large $\left(\sim 230 \mathrm{~km}^{2}\right)$, discordant, Late Protero-zoic, post-orogenic pluton in the Egersund-Farsund Igneous Province. The intrusion was em-placed shortly after massif-type anorthosite plutons and is cut by jotunite dykes. It contains a $>7000 \mathrm{~m}$ thick Layered Series consisting of rocks belonging to the anorthosite kindred: andes-ine anorthosite, leuconorite, troctolite, norite, gabbronorite, mangerite, and quartz mangerite. Cumulates in the Layered Series are organized in 6 megacyclic units (MCU 0 to IV), individually up to $1800 \mathrm{~m}$ thick, but varying considerably in thickness and development along strike. The highest-temperature cumulates are troctolites containing plagioclase of $\sim \mathrm{An}_{54}$ and olivine of $\sim \mathrm{Fo}_{77} \cdot \mathrm{Phase}$ contacts in the macrocyclic units reflect crystallization of the silicate minerals in the order plagioclase $( \pm$ olivine), orthopyroxene, Ca-rich pyroxene, pigeonite. Il-menite crystallized early and apatite appeared as a cumulus mineral at about the same time as Ca-rich pyroxene. Cumulus magnetite followed orthopyroxene and preceded Ca-rich pyroxene in MCU III and $\Gamma \mathrm{V}$, but crystallized after Ca-rich pyroxene in MCU IB. MCUs 0 , IA and II do not contain cumulates with cumulus magnetite or Ca-rich pyroxene. Olivine $\left(\sim \mathrm{Fo}_{50}\right)$ reappears in the uppermost part of the Layered Series where there is a rapid stratigraphic transition to mangerite and quartz mangerite. The basal parts of MCUs III and $\Gamma \mathrm{V}$ are characterized by thin sequences of plagioclase, plagioclaseorthopyroxene-ilmenite and orthopyroxene-ilmenite cumulates in which there are systematic upward decreases in initial $\mathrm{Sr}$ isotope ratios. They are overlain by troctolite (plagioclase-olivine cumulate) and are believed to have crystallized from hybrid magmas. The MCUs, the discordant geometry of phase contacts, the stratigraphic variations in initial ${ }^{87} \mathrm{Sr} /{ }^{86} \mathrm{Sr}$ ratio $(0.7049-0.7085)$, and the abundance of xenoliths suggest crystallization of the cumulates at the base of a periodically-replenished, compositionally-zoned magma chamber that was continually assimilating country rocks. The parent, as indicated by medium-grained jotunite along country-rock contacts, appears to have been an evolved, Ti-rich magma similar to ferrobasalt, but poor in diopside components. Systematic stratigraphic variations in initial ${ }^{87} \mathrm{Sr} /{ }^{86} \mathrm{Sr}$ ratio at the base of MCU II and MCU IV suggest that influx of magma into the chamber was accompanied by mixing with resident, contaminated magma.
\end{abstract}

\section{INTRODUCTION}

The Bjerkreim-Sokndal Intrusion (BKSK) (Michot, 1960, 1965; Duchesne, 1987) is a large (40 km long and up to $15 \mathrm{~km}$ wide) layered intrusion that occupies an area of about $230 \mathrm{~km}$ (Figure 1). Lithologically the intrusion consists of rock types belonging to the anorthosite kindred; i.e. andesine anorthosite, troctolite, leuconorite, norite, gabbronorite, jotunite (monzonorite), mangerite (hypersthene monzonite) and quartz mangerite. The BKSK is em-placed in granulite-facies quartzo-feldspathic and mafic gneisses as well as anorthosite and leuconorite belonging to the Egersund-Ogna (Michot and Michot, 1970; Duchesne and Maquil, 1987) HalandHelleren (Michot, 1961) and Ána-Sira (Krause et al., 1985; Duchesne and Michot, 1987) massifs, and xenoliths of all these host rocks are common within the intrusion itself (Duchesne, 1970). Zircons within an orthopyroxene megacryst from the Egersund-Ogna anorthosite have recently yielded an U-Pb age of 929 $2 \mathrm{Ma}$ (Schärer et al., 1992).

The BKSK and the various anorthosite massifs are cut by members of a suite of small plutons and wide, laterally-persistent dykes of jotunite, some of which are differentiated (Duchesne et al., 1989; Wilmart et al., 1989). The most voluminous of the jotunite dykes that cut the northern part of the BKSK is the Lomland dyke (Duchesne et al., 1989) (Figure 1). Zircon and baddeleyite from the Tellnes ilmenite norite, belonging to the same suite of intrusions, have yielded U-Pb ages of $920 \pm 2 \mathrm{Ma}$ (Schärer et al., 1992; Duchesne et al., 1993). The BKSK is also cut by members of the Egersund swarm of basaltic dykes (Figure 1), that were intruded at 630-650 Ma (Sundvoll, 1987).

Several workers have suggested that the BKSK was emplaced in two quite separate stages: crystallization of the 
lower part of the pluton, the Layered Series (generally referred to as the "leuconoritic phase"), taking place long before the overlying mangerite and quartz mangerite (Wielens et al., 1980; Rietmeijer, 1984). The present authors do not ascribe to this view but regard the BKSK as a single, differentiated intrusion, emplaced in the course of a relatively short-lived ( $\sim 10 \mathrm{Ma})$, post-Sveconorwegian (= post-Grenvillian) magmatic event, together with anorthosite massifs and jotunite intrusions (Duchesne et al, 1993).

This paper gives a review of present knowledge of the BKSK and presents evidence for development of its cumulates in a repeatedly-replenished, continuously-fractionating magma chamber in which country rocks were assimilated. Evidence is also presented for the development of compositional stratification of the magma, and the nature of the parental magma is discussed. The description deals principally with the Bjerkreim lobe of the intrusion where the Layered Series is most completely developed.

\section{PLUTONIC SETTING OF THE BJERKREIM-SOKNDAL INTRUSION}

The BKSK is part of the autochthon that appears south of the Caledonian nappe complex of the Stavanger area and forms part of the Sveconorwegian (= Grenvillian) Orogen. The autochthon in southwest Norway is composed of migmatitic ortho- and paragneisses, together with isolated occurrences of supracrustal rocks and synorogenic syenites and granitoids (Hermans et al, 1975). The gneisses and metasediments are intruded by post-Sveconorwegian plutons, including the BKSK, that constitute the Egersund-Farsund Igneous Province. Individual intrusions in the province vary in composition from andesine anorthosite and leuconorite (which dominate in terms of area), to norite, jotunite, syenite, charnockite, and granite. The structural and metamorphic history of the gneissic envelope to the BKSK was complex and protracted. Intense Sveconorwegian deformation was coeval with upper amphibolite to granulite facies metamorphism (Ml) at pressures of 5-7 kb (Jansen et al, 1985; Maijer, 1987). M2 intermediate pressure (4-6 kb) granulite-facies metamorphism increased in grade towards the Egersund-Farsund Igneous Province as marked by isograds that follow its margin (Tobi et al., 1985; Jansen et al., 1985). M2 metamorphic assemblages were variably overprinted during the retrogressive M3 metamorphic event (at 3-5 kb, Jansen et al, 1985).

The depth at which the BKSK crystallized has been estimated from the mineral assemblages present in mangerite and quartz mangerite. The coexistence of $\mathrm{Fo}_{6}+$ quartz and evidence of primary orthopyroxene with a composition of $\mathrm{Wo}_{2} \mathrm{En}_{15} \mathrm{Fs}_{83}$ (Rietmeijer, 1979) bracket pressures to 5.7-7.5 kb using the Bohlen and Boettcher (1981) geobarometer (Wilmart and Duchesne, 1987). The low $\mathrm{Al}_{2} \mathrm{O}_{3}$ contents of orthopyroxenes in the BKSK suggest, however, that crystallization took place at pressures less than $5 \mathrm{~kb}$ (Vander Auwera and Longhi, 1994).

\section{THE FORM OF THE BJERKREIM-SOKNDAL INTRUSION}

The Bjerkreim-Sokndal Intrusion has generally been described as a lopolith, but recent detailed mapping shows it to be a trough-like, discordant intrusion. Modelling of the associated $+10-30$ mgal gravity anomaly gives a minimum depth to the base of the intrusion of about $4 \mathrm{~km}$ (Smithson and Ramberg, 1979).

Layering within the intrusion is deformed into a deep, doubly-plunging syncline that branches in the south around a dome cored by the Ana-Sira anorthosite massif (Figure 1). The core of the syncline is occupied by massive quartz mangerite, which does not exhibit modal or textural layering, and this is separated in places from the underlying mangerite by a zone rich in wall-rock xenoliths. The size of the gravity lows over the quartz mangerite suggests a maximum thickness of about $2 \mathrm{~km}$ (Smithson and Ramberg, 1979). There is no evidence that the roof of the intrusion is preserved anywhere within the confines of the present outcrop.

The BKSK consists of three lobes; the Bjerkreim lobe in the northwest, and the smaller Sokndal and Mydland lobes to the south and south-east respectively (Figure 1). Modal layering and phase contacts in the Bjerkreim lobe are disposed in a syncline that plunges southeast at $20-40^{\circ}$. In the steep limbs of the syncline the cumulates are generally foliated, essentially in the plane of the modal layering. In places, cumulus minerals form augen in a foliated matrix, small shear zones are developed, and there is a strong mineral lineation. Linear fabrics dominate around the hinge of the syncline (Paludan et al., 1994). Cumulus plagioclase grains are strained or recrystallized to shape-oriented polygonal aggregates, while prismatic Ca-poor pyroxenes are commonly kinked or bent. Uniform paleomagnetic vectors in different parts of the intrusion (Poorter, 1972) suggest that the deformation and development of the synformal disposition of the layering took place at temperatures in excess of the Curie point $\left(550-650^{\circ} \mathrm{C}\right)$. Michot and Michot $(1970)$ and others have attempted to relate the deformation to a late expression of the Sveconorwegian Orogeny. Since the age of emplacement appears to be $\sim 70 \mathrm{Ma}$ later than the last recorded regional deformation, the crystallization and deformation of the BKSK must have taken place entirely in a anorogenic environment. The foliation, mineral lineation and the synformal disposition of the 
Layered Series seem, therefore, to be due to high-temperature, gravitational foundering (Glazner, 1994) consequent on the crustal-scale density inversion (demonstrated by the present gravity anomaly) that resulted from the location of the BKSK within lower-density gneiss and anorthosite

Figure 1. Location (A), simplified geological map of the Bjerkreim-Sokndal Layered Intrusion (B), and the distribution of megacyclic units 0 to $I V$ in the Bjerkreim lobe of the intrusion $(C)$. In Figure $1 B$, intrusions marked as $M$ are jotunite and those marked as D are basaltic dykes belonging to the Egersund Swarm. In Fig $1 C, M G=$ mangerite, $Q M G=$ quartz man-gerite, $T Z=$ Transition Zone, $M Z=$ Marginal Zone (jotunite, norite, and leuconorite).

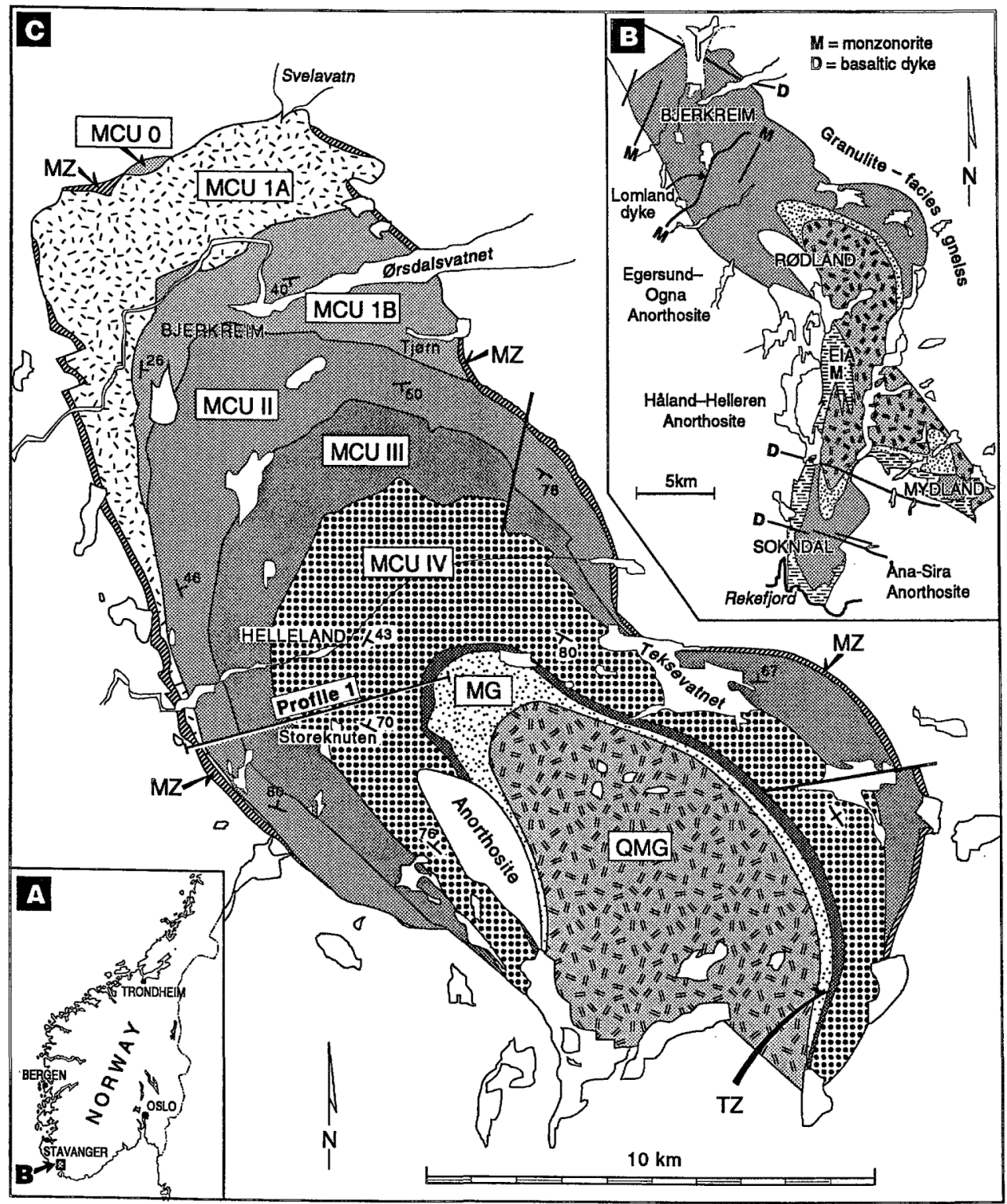




\section{SUBDIVISION OF THE LAYERED SERIES}

The Layered Series has a thickness of $>7000 \mathrm{~m}$ in the axial region of the syncline and can be divided into 6 megacyclic units (MCU 0 to IV) which repeat characteristic sequences of cumulates (Figures 1 and 2). The numbering of Michot $(1960,1965)$ has been retained as far as pos sible in that his units 2,3 , and 4 are referred to as MCU II, III, and IV, in agreement with papers by Nielsen and Wilson (1991) and Jensen et al. (1993). We have not been able to confirm the existence of Michot's unit 5 and consider that MCU IV grades into the Transition Zone (Figure 3). A consequence of the numbering system is that we refer to the lowest three units as MCU O, IA and IB. The megacyclic units can be further subdivided into zones a-f, based on assemblages of cumulus minerals (Figure 2).

The megacyclic units vary in stratigraphic thickness, lateral persistence and in the nature of the layer sequences they exhibit. The lower three megacyclic units, exposed only in the northernmost part of the intrusion, are individually as much as $1300 \mathrm{~m}$ thick but show a pronounced southward thinning in the western limb of the syncline and are not developed in the southern parts of the Bjerkreim lobe.

The lowermost cumulates are exposed in the northwestern part of the Bjerkreim lobe and consist of plagioclasehypersthene-ilmenite cumulates (phiC). They are regarded as the top of MCU 0, the rest of which, together with an unknown thickness of cumulates, is hidden. These cumulates are overlain successively by $\mathrm{pC}, \mathrm{piC}$ and $\mathrm{phC}$ belonging to MCU IA ( $\sim 1300 \mathrm{~m}$ thick in a profile along the axial trace of the syncline). This sequence is repeated in MCU IB ( $\sim 875 \mathrm{~m}$ thick) which also contains more evolved lithologies with the entry of cumulus Carich pyroxene, followed by magnetite. MCUs 0-IB are characterized by the presence of plagioclase megacrysts (up to $10 \mathrm{~cm}$ long) in all rocks with the exception of the most evolved cumulates at the top of MCU IB.

MCU II (reaching a thickness of $1300 \mathrm{~m}$ ) consists of a thin layer of magnetite-bearing piC overlain by phiC. The appearance of cumulus magnetite in the leuconorites at the base of MCU II and its absence in the overlying cumulates suggests affinities with the olivine-bearing zones near the bases of succeeding MCUs.

MCU III (maximum $\sim 1300 \mathrm{~m}$ thick) has, in places, a thin zone consisting mainly of pC, but with interlayered iC, phiC, and hiC at the base (Zone IIIa in Figure 2), overlain by leucotrocto-lite that contains cumulus magnetite in addition to plagioclase, olivine and ilmenite. The leuco-troctolite is in turn overlain by phiC (in places with an intervening thin piC), followed by magnetite norite and gabbronorite with the successive (re-)entry of cumulus magnetite and then apatite together with Ca-rich pyroxene.

MCU IV (maximum thickness $\sim 1800 \mathrm{~m}$ ) repeats the same sequence as in MCU III. MCU IV contains, however, additional, more-evolved cumulates. Michot (1960) recognized the prominent olivine-bearing zone near the base of MCU IV and referred to it as the "Svalestad horizon". It has a thickness of about $100 \mathrm{~m}$ and is laterally persistent along strike for about $24 \mathrm{~km}$. Olivines in the olivine-bearing zones near the bases of MCU III and IV are partially or completely replaced by orthopyroxene-Fe-Ti oxide symplectites, but the zones are texturally distinctive even where olivine is absent. Small amounts of biotite and hornblende also occur in the olivinebearing zones. Ca-poor pyroxene is inverted pigeonite in the upper part of MCUIV which grades into overlying mangerite through a jotunitic Transition Zone (TZ) whose base is defined by the entry of Fe-rich olivine, which more or less coincides with the appearance of interstitial alkali feldspar (Duchesne et al., 1987). With the appearance of cumulus mesoperthite the rocks grade upwards from jotunite to mangerite, which in turn passes into massive quartz mangerite. Even in these highly-evolved rocks, hydrous phases are not abundant: calcic amphibole is generally a minor mineral (except in the uppermost part of the quartz mangerite where it may occur as large oikocrysts) and biotite is generally an accessory mineral. The aggregate thickness of the mangerite and quartz mangerite is $>350 \mathrm{~m}$ (Rietmeijer, 1979) and may be as much as $2.5 \mathrm{~km}$. Viewed on a broad scale (Figure 2 ), the lower part of the Layered Series is dominated by plagioclase cumulates, the middle part by plagioclasehypersthene-ilmenite cumulates and the upper part by plagioclase-hypersthene/pigeonite-augite-ilmenitemagnetite-apatite cumulates. Combined with the reversals to relatively primitive mineral assemblages at the bases of the MCUs, this is strong, first-order evidence that the Layered Series crystallized in a continuouslyfractionating, periodically-replenished magma chamber. The base of MCU $\Gamma \mathrm{V}$ seems to reflect the last major influx of magma into the BKSK magma chamber. After this event fractional crystallization was relatively uninterrupted, though there is some mineralogical evidence of a minor regressive discontinuity in the cryptic layering at the base of the TZ. 
Figure 2. Generalized stratigraphy of the Bjerkreim-Sokndal Layered Series as developed in the northern part of the intrusion along the axial trace of the syncline defined by the layering. The lower case letters ( $a, b, c, d, e$, and f) refer to stratigraphic zones that are characterized by different assemblages of cumulus minerals.

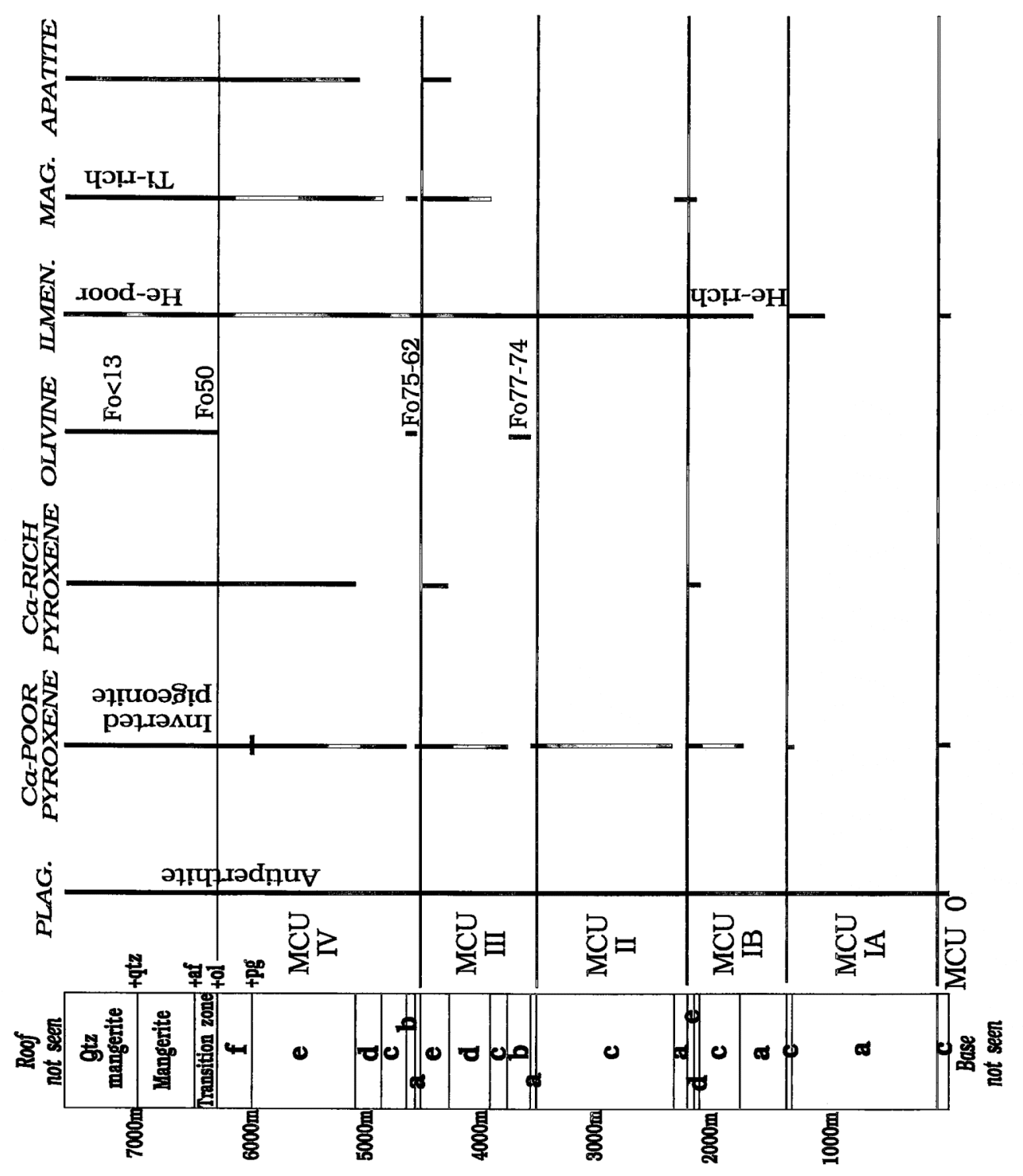

\section{THE GEOMETRY OF PHASE CONTACTS}

A prominent feature of the Layered Series is the discordant geometry of phase contacts within individual megacyclic units. The angles which phase contacts subtend with boundaries between MCUs $\left(2-15^{\circ}\right)$ have the result that zones characterized by particular cumulus assemblages may wedge out laterally. This is particularly prominent in MCUs IB and II where the basal plagioclase cumulates have maximum thicknesses of around 800 and $170 \mathrm{~m}$ respectively where they abut the northeastern margin of the Bjerkreim lobe, but they thin to the southwest and eventually disappear. The most evolved cumulates in MCU IB also pinch out in a southwesterly direction, so that the unit cannot be recognized further along strike (Figure 1), but they extend beyond the termination of the associated basal piC. 
The two basal zones of MCU III (MCU IIIa and the olivine-bearing MCU IIIb) can be traced for about $19 \mathrm{~km}$ from the southwestern flank of the Bjerkreim lobe where they abut onto anorthosites of the Haland-Helleren massif, round the hinge zone of the syncline, to the northern flank. Here these two zones thin gradually towards the south-east and wedge out completely approaching the Teksevatnet area where phiC of MCU ПIc overlies apparently identical phiC of MCU IIc. The country-rock gneisses form a protrusion in the Teksevatnet area, to the east of which only MCUs III and IV appear to be developed. These relationships are illustrated in Figure 3 which is based on seven profiles studied in detail by Nielsen and Wilson (1991). The base of MCUIV is in contact with modally layered cumulates of MCU IIIe in all the profiles except D (in Figure 3) where it overlies MCU Hid. The olivine-bearing zone (MCU IVb) has a fairly constant thickness $(75-100 \mathrm{~m})$ along its entire strike length of-24 km, whereas the underlying MCU IVa is absent on the northern flank, reaches a maximum thickness of $-90 \mathrm{~m}$ in profile D in the central, axial region where MCU IIIe is absent, and thins towards the southern flank where it has a thickness of about $10 \mathrm{~m}$. MCU IVc varies in thickness from about 40-100 m, but this variation does not appear to be related to the location of the profiles.

These geometrical relationships imply that contrasting cumulus assemblages crystallized simultaneously on different parts of the magma-chamber floor. At certain times, higher temperature cumulus assemblages were forming on the central, deeper regions of the floor while lower temperature cumulates were precipitating towards the margins of the chamber. We believe that the geometry of phase boundaries in the BKSK is a result of an interaction between vertical compositional gradients in the magma column and a basinal or half-basinal floor to the chamber, as will be discussed later.

\section{MODAL LAYERING}

The BKSK displays small-scale modal and textural layering in zones characterized by two or more cumulus minerals, and modal layering is usually particularly well developed in the upper, more mafic parts of the MCUs. Igneous lamination is almost ubiquitous, but commonly is overprinted by a deformational fabric.

Layers commonly exhibit modal grading from pyroxene, ilmenite or magnetite-rich bases to plagioclase-rich tops (Figure 4A). Modal grading in the lower part of the Layered Series, where plagioclase megacrysts are present, is accompanied by reverse size grading, the megacrysts being concentrated towards the tops of modallygraded layers. Thicker isomodal layers generally separate modally-graded layers (Figure 4A). Isomodal layers of ilmenite py-roxenite and ilmenitite are common in the basal zones of MCUs III and IV. A unique thin, discontinuous layer of pyrrhotite pyroxenite is found just beneath the base of MCU III where it is associated with disseminated sulphides in both the underlying and overlying phiC. The TZ in the Sokndal lobe is characterized by the occurrence of isomodal ultramafic layers up to $4 \mathrm{~m}$ thick consisting of cumulus Fe-Ti oxides, pyroxene and Fe-rich olivine (Duchesne et al., 1987).

Modally-layered intervals sometimes display slump structures. Trough structures and minor unconformities are developed locally (Figure 4B).

Figure 3. The geometrical arrangement of zones during crystallization of the upper part of the Layered Series in the Bjerkreim lobe (based on Nielsen and Wilson, 1991), The vertical exaggeration is x2. The thicknesses of individual zones is measured from the entry of cumulus pigeonite (inverted) which is shown as a reference line the top of the figure. Faults are not shown. Recent detailed mapping has shown that zone IMe terminates abruptly towards the centre of the intrusion, rather than wedging out.

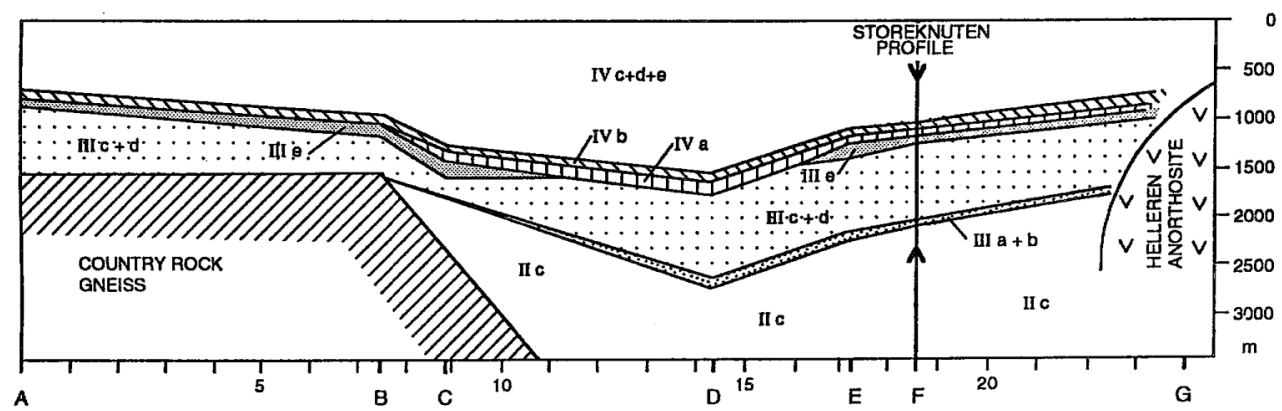


Figure 4. A) Modally-graded layers alternating with more homogeneous ilmenite-magnetite gabbronorite (phaimC) within MCU Hie (Figure 2) near Storeknuten (Figure 1C). Strati-graphic top is to the right (NE). B) Minor erosional unconformity in steeply dipping, modally layered ilmenite-magnetite norite (phim C) within MCU Hid (Figure 2) on the northern shore of Teksevatnet (Figure 1C). Stratigraphic top is to the left (SW). Boot print for scale.
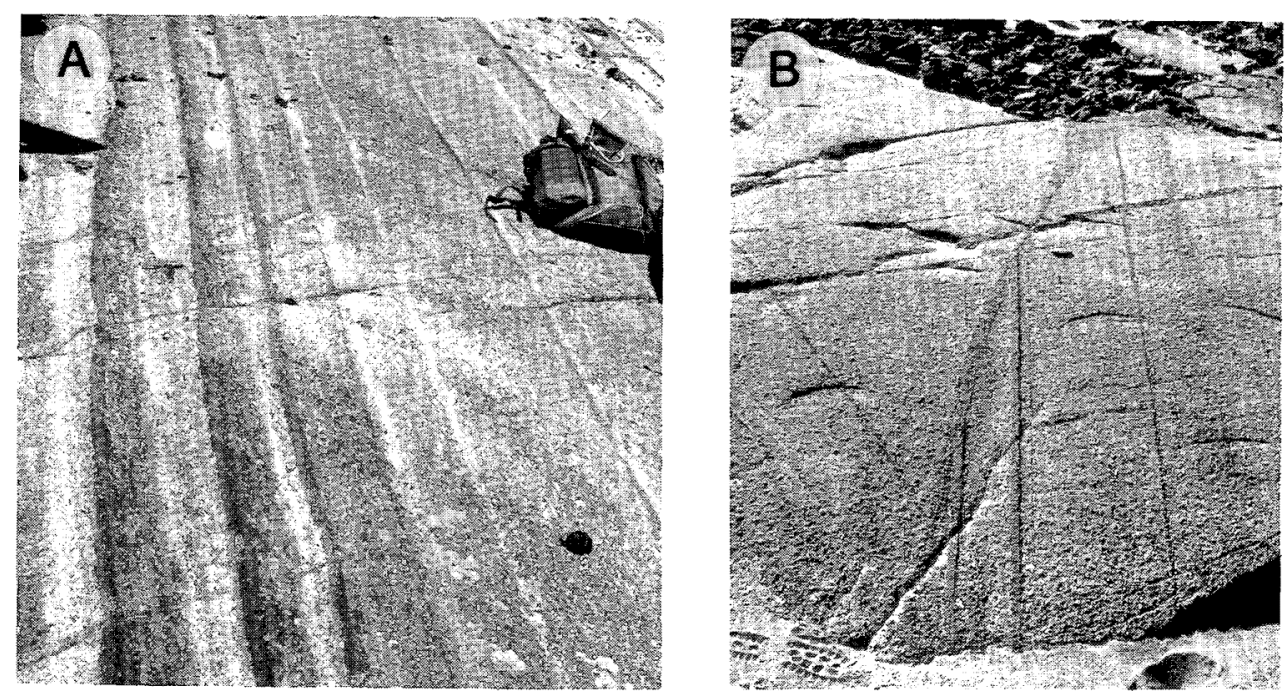

\section{INCLUSIONS}

Large rounded to slab-like inclusions (up to $600 \mathrm{x} 400 \mathrm{~m}$ ) of massive or foliated anorthosite and leuconorite are common in the lower part of the Layered Series and in the south west part of the Bjerkreim lobe. These are believed to be derived from the adjacent Egersund-Ogna and Hăland-Helleren anorthosite massifs. Based on the work of Michot (1961), the Hăland part of the latter massif was previously thought to intrude the southern flank of the Bjerkreim lobe of the BKSK in the Rǿdland area; our detailed mapping has shown that the BKSK cuts anorthosite and leuconorite which in this area form abundant, large inclusions. This implies not only that the BKSK is younger than all of the anorthosite plutons, but also that the inclusion of foliated anorthositic rocks indicates that emplacement took place after the deformation of at least parts of the anorthosite massifs.

Xenoliths of anorthosite and leuconorite are particularly frequent in the plagioclase cumulates in MCUs IA and IB. In these megacyclic units there appears to be an upward decrease in both the number and size of the leucocratic xenoliths. Blocks of quartzo-feldspathic gneiss and mafic granulite are especially abundant in the upper part of the Layered Series and are believed to have been derived from the roof. Large gneissic xenoliths are numerous in the upper part of MCU IV and extend into the TZ and mangerite. The presence of a zone rich in gneissic xenoliths, the "septum xenolithique" of Michot (1960), in the vicinity of the contact between the mangerite and quartz mangerite has long been recognized.

\section{MINERAL CHEMISTRY}

The compositional variations in plagioclase and Ca-poor pyroxene with stratigraphic height as displayed along the profile marked in Figure 1 are presented in Figure 5.

Plagioclase is the dominant cumulus mineral in the BKSK and is unusually sodic. It shows surprisingly little systematic, stratigraphic or lateral variation in composition in the lower part of the Layered Series. There also seems to be little systematic correlation between the composition of plagioclase and the cumulus paragenesis. Plagioclase in thin sections typically exhibits no compositional zoning but there are significant compositional differences between individual grains. This is believed to be the result of the recrystallization of cumulus crystals that originally were compositionally zoned. In MCU IA and IB plagioclases are in the range An $\mathrm{An}_{4-36}$. At the base of MCU II there is a distinct regression to slightly more calcic plagioclase (An52-43).

In Figure 5 plagioclase has a composition of $\mathrm{An}_{50}$ in the basal, marginal leuconorites, and becomes slightly more sodic upwards, reaching $\mathrm{An}_{45}$ near the top of MCU II. There is a reversal to about $\mathrm{An}_{51}$ at the base of MCU III, 
followed by a trend to slightly more evolved compositions upwards, reaching $\mathrm{An}_{46}$ in MCU IIIe. There is an abrupt reversal to the most calcic plagioclase compositions in the entire BKSK intrusion $\left(\mathrm{An}_{54}\right)$ at the base of MCU IV (shown in more detail in Figure 6). This is followed by a systematic trend to more evolved plagioclase compositions through the $\sim 2000$ m-thick MCU IV, reaching $A_{37}$ near the top. Plagioclase in the TZ changes rapidly from $\mathrm{An}_{37}$ to about $\mathrm{An}_{24}$ in the mangerite. According to Rietmeijer (1979) plagioclase in mangerite and quartz mangerite varies between $\mathrm{An}_{43}$ and $\mathrm{An}_{14}$. Plagioclase in the upper part of MCU IV is typically antiperthitic. Antiperthite also occurs sporadically in the lower megacyclic units. Sr concentrations in plagioclase vary between 1500 and $850 \mathrm{ppm}$ and are not simply correlated with the anorthite content. Sr decreases with falling an-orthite content until Ca-rich pyroxene and apatite appear as cumulus phases, after which Sr increases as plagioclase becomes more albitic, reaches a maximum on the appearance of cumulus alkali feldspar, and then decreases (Duchesne, 1978).

Ca-poor pyroxene in $\mathrm{MCU}$ IA and IB has $100 \mathrm{Mg} / \mathrm{Mg}+\mathrm{Fe}(\mathrm{Mg} \#)$ between 75 and 63. Ca-poor pyroxene

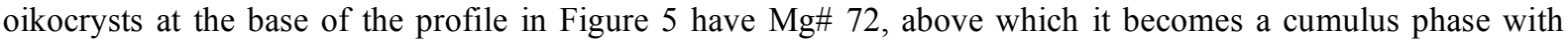
about Mg\# 74. This composition persists into the lower part of MCU ПI, above which the Ca-poor pyroxene becomes gradually more evolved, reaching Mg\# 70 in the upper part of MCU III. There is a reversal to Mg\# 74 at the base of MCU IV, followed by a trend to more iron-rich compositions, reaching $\mathrm{Mg \#} 55$ in inverted pigeonite at the top of MCU IV. There is an abrupt decrease to Mg\# 28 in inverted pigeonite oikocrysts across the MCU IV - TZ boundary in Figure 5, followed by a slight increase to Mg\# 32 in the mangerite. Elsewhere in the Bjerkreim lobe there is a gradual regression in the cryptic variation beneath the MCU IV - TZ boundary and the $\mathrm{TZ}$ contains inverted pigeonite with $\mathrm{Mg} \#$ of 57-43 while the mangerite contains more Fe-rich compositions (e.g. Mg\# 32). The TZ in the Sokndal lobe appears to be anomalous in that its lower part reportedly contains cumulus Fe-rich orthopyroxene with Mg\# from 34 to 24 (Rietmeijer, 1979), rather than inverted pigeonite. The upper part of the TZ and the overlying mangerite, however, contain inverted pigeonite with $\mathrm{Mg \#}$ between 31 and 25 (Rietmeijer, 1979), partly as large oikocrysts.

Ca-poor pyroxene in the $\mathrm{BKSK}$ is much poorer in $\mathrm{Al}_{2} \mathrm{O}_{3}$ than pyroxene megacrysts of comparable $\mathrm{Mg \#}$ in the adjacent anorthosite massifs. The BKSK pyroxenes contain 0.9-2.6 wt \% $\mathrm{Al}_{2} \mathrm{O}_{3}$ compared to 7-9 \% in the anorthosites (Duchesne and Michot, 1987).

Figure 5. Stratigraphic variations in the compositions of cumulus plagioclase and Ca-poor pyroxene as well as whole-rock initial Sr isotope ratios along profile 1 (Figure 1C). Based on Nielsen et al. (1996).

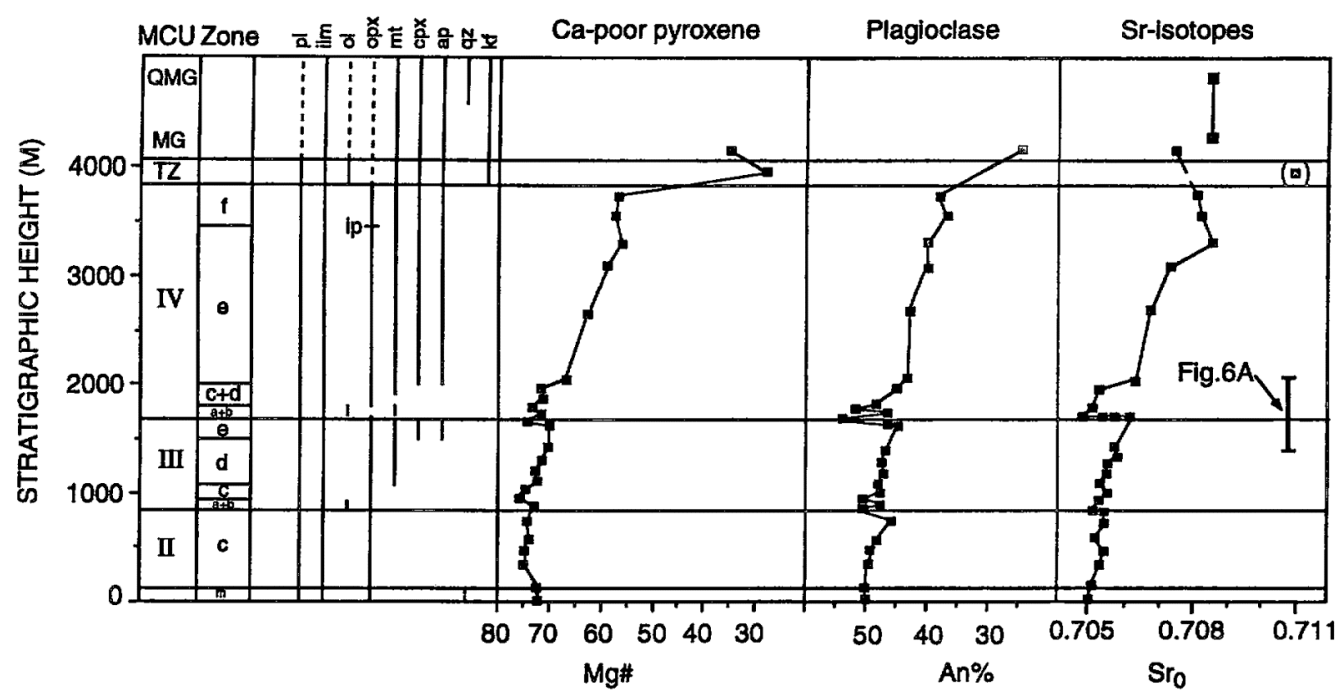

Ca-rich pyroxene has a more restricted distribution than Ca-poor pyroxene: It is only found as a cumulus mineral in the upper parts of MCUs IB, III, and IV, as well as in the TZ, mangerite and quartz mangerite. Ca-rich pyroxene in MCUs IB and III has the composition $\mathrm{Ca}_{45-42} \mathrm{Mg}_{43-40} \mathrm{Fe}_{16-14}(\mathrm{Mg} \#$ 71-75). Through MCU IV the Mg\# in Ca-rich pyroxene decreases upwards from 75 to about 62 . The TZ is characterized by Ca-rich pyroxenes with Mg\# between 69 and 45 (Duchesne et al., 1987). In the mangerite and quartz mangerite Ca-rich pyroxenes have $\mathrm{Mg} \#$ in the range 42-15 (Rietmeijer, 1979). Ca-rich pyroxene is the only pyroxene present in the upper part of the quartz mangerite. 
Olivine is restricted in occurrence in the lower part of the Layered Series, as noted above, principally to two stratigraphic intervals near the bases of MCUs III and IV. It has a composition of $\mathrm{Fo}_{77-74}$ in MCU IIIb, while MCU IVb is characterized by olivine of $\mathrm{Fo}_{75-62}$. Iron-rich olivine re-appears in the Transition Zone and changes rapidly in composition from $\mathrm{Fo}_{50}$ to $\mathrm{Fo}_{19}$ over a stratigraphic thickness of 50-80 m. Mangerite and quartz mangerite contain $\mathrm{Fo}_{13-4}$ (Rietmeijer, 1979).

IImenite exhibits a general decrease in hematite content through the Layered Series, from 16-20\% in the lower part of the series where it is the only cumulus Fe-Ti oxide, to about $2 \%$ in the mangerite and quartz mangerite (Duchesne, 1972). This pattern is repeated on a smaller scale in the individual MCUs. Ilmenite contains about $0.3 \% \mathrm{~V}_{2} \mathrm{O}_{3}$ in the lower part of the Layered Series and vanadium shows an identical variation to haematite content. Manganese in ilmenite, however, increases almost continuously through the Layered Series, from about $0.3 \%$ in leuconorites near the base to $1.0 \% \mathrm{MnO}$ in mangerite; breaks in the trend at contacts between MCUs are slight. Nickel and chromium are enriched in ilmenite at the bases of MCUs where concentrations can be as high as $1000 \mathrm{ppm} \mathrm{Ni}$ and $1.4 \% \mathrm{Cr}_{2} \mathrm{O}_{3}$.

Magnetite is a cumulus phase in the upper parts of MCUs IB, III, and IV, in the TZ where it occurs in oxide-rich layers, and in the leuconorites and leucotroctolites near the bases of MCUs II, III, and IV. Its $\mathrm{TiO}_{2}$ content increases systematically from $<2 \%$ at its reappearance in the upper part of MCU III to as much as $19 \%$ (corresponding to $\mathrm{Usp}_{58} \mathrm{Mt}_{42}$ ) in the $\mathrm{TZ}$. As with ilmenite, the manganese concentrations increase (to $\sim 0.25 \%$ at the top of MCU IV) and vanadium decreases upwards through the Layered Series (from $\sim 1.3 \%$ to $0.02 \% \mathrm{~V}_{2} \mathrm{O}_{3}$ at the top of MCU IV) (Duchesne, 1972). Magnetite in leucotroctolite at the base of MCU IV contains lower V concentrations (1.0-0.75\% $\left.\mathrm{V}_{2} \mathrm{O}_{3}\right)$ than the magnetite in the uppermost part of MCU III and on its reappearance in the upper part of MCU IV, possibly due to the presence in the leucotroctolite of small amounts of amphibole that has a high partition coefficient for $\mathrm{V}$ (Jensen et al., 1993). Ni concentrations are generally low $(<40 \mathrm{ppm})$, except in the leucotroctolites at the bases of MCUs III and IV where concentrations are 900-600 ppm. Nickel concentrations decrease with stratigraphic height in the leucotroctolite at the base of MCU IV. Chromium exhibits the same behaviour as $\mathrm{Ni}$, concentrations in the leucotroctolite at the base of MCU IV varying from 1.4$0.4 \% \mathrm{Cr}_{2} \mathrm{O}_{3}$. Chromium contents in magnetite elsewhere in the BKSK are very low.

Apatite is a cumulus mineral in the uppermost parts of MCUs III and IV and in mangerite. It exhibits lightelement enriched chondrite-normalized REE patterns with pronounced negative Eu-anomalies (Roelandts and Duchesne, 1979; Holdam, 1990). The concentration of REE in cumulus apatite increases significantly from MCU III to the mangerite, but there is at present insufficient data to document any cryptic variation which may be present in individual megacyclic units.

\section{Sr ISOTOPE RATIOS}

Initial ${ }^{87} \mathrm{Sr} /{ }^{86} \mathrm{Sr}$ ratios $\left(\mathrm{Sr}_{0}\right)$ (recalculated for an age of $930 \mathrm{Ma}$ ) for rocks and minerals from the BKSK lie between 0.7049-0.7085, with the highest values being found in mangerite and quartz mangerite (Versteeve, 1975; Demaiffe et al., 1979; Wielens et al., 1980; Jensen et al., 1993). A Sr isotope study of the Bjerkreim lobe of BKSK has recently been carried out by Nielsen et al (1996), whose results are shown in Figures 5 and 6 . The variation in $\mathrm{Sr}_{0}$ in Figure 5 is broadly parallel to the variation in $\mathrm{An} \%$ in plagioclase and $\mathrm{Mg} \#$ in $\mathrm{Ca}$-poor pyroxene, showing that there is a close relationship between fractionation and contamination in $\mathrm{BKSK} \mathrm{Sr}_{0}$ shows an overall increase through the first $\sim 3400 \mathrm{~m}$ in Figure 5 from about 0.7050 to 0.7085 . Superimposed on this trend is a major reversal to lower $\mathrm{Sr}_{0}$ values (reaching 0.7049) at the base of MCU IV, and a minor, indistinct reversal at the base of MCU III. Above $3400 \mathrm{~m}$ the correlation with mineral composition breaks down, with $\mathrm{Sr}_{0}$ decreasing slightly and reaching constant values of 0.7085 in the quartz mangerite.

The fact that the lowermost sample at the base of the profile in Figure 5, collected from close to the country rock contact, has a relatively low $\mathrm{Sr}_{0}$ value (0.7050) implies that there is little local contamination from the gneissic country rock $\left(\mathrm{Sr}_{0}=0.7196\right.$; Versteeve, 1975) which forms the floor in this part of the intrusion.

Previous workers (Demaiffe et al, 1979) considered that the Layered Series had $\mathrm{Sr}_{0}$ values around 0.705-0.706, considerably lower than the mangerite and quartz mangerite $(0.7085)$. This apparently significant difference in isotopic ratios was used as a major argument against a direct genetic relationship between these two major parts of the complex (Wiebe, 1984). The gradual increase in $\mathrm{Sr}_{0}$ through MCU IV, ending with fairly constant values in the mangerite and quartz mangerite, combined with the field, mineralogical and cryptic variations, implies that the two parts of the complex are related. 
Figure 6. A) Stratigraphic variations in mineral compositions and Sr-isotopes (both whole-rock and in separated plagioclase) across the MCU III - MCU IV boundary at Storeknuten (Figure 1C). Ca-poor pyroxene in MCU IVb replaced olivine and is not a cumulus phase. B) The detailed compositional variations at the base of MCU IV at Storeknuten. Based on Nielsen et al. (1996).

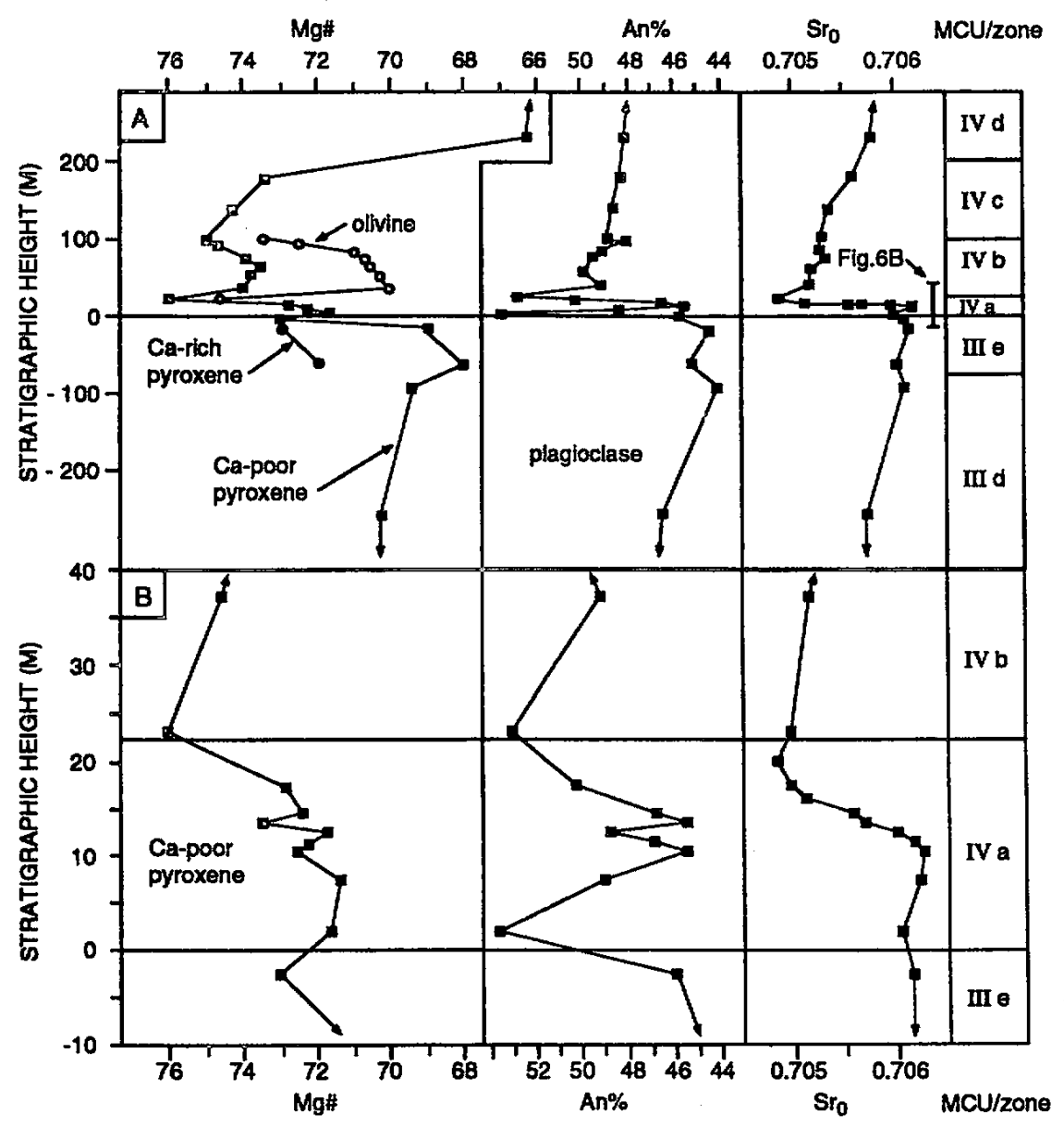

\section{VARIATIONS ACROSS THE MCU III-IV BOUNDARY}

The most primitive rocks in the entire Bjerkreim-Sokndal intrusion occur near the base of MCU IV in MCU IVb (Figures 5 and 6). A detailed section across this boundary (at Storeknuten, on profile 1 in Figure 1) was investigated by Jensen et al. (1993). The Storeknuten profile is part of profile F in Figure 3 which is based on Nielsen and Wilson (1991). Further details of the Storeknuten section have been studied by Nielsen et al. (1996). Some of the results of these studies are included here.

Figure $6 \mathrm{~A}$ shows the lithological variation in a $\sim 600 \mathrm{~m}$ thick section, together with compositional variations of the major silicates and variations in $\mathrm{Sr}_{0}$. The modally layered phimC of MCU IIId about $250 \mathrm{~m}$ below the base of MCU IV contains plagioclase and Ca-poor pyroxenes with $\mathrm{An}_{47}$ and $\mathrm{Mg} \# 70$ respectively, together with an $\mathrm{Sr}_{0}$ of 0.7058 in separated plagioclase. Slightly more evolved mineral compositions, and systematically higher $\operatorname{Sr}_{0}$ values occur at the top of MCU IIId and in the phimcaC of MCU IIIe. A few meters below the base of MCU IV (Figure 6B) plagioclase and Ca-poor pyroxene show compositional reversals from $\mathrm{An}_{44}$ to $\mathrm{An}_{46}$ and from $\mathrm{Mg \#}$ 69 to $\mathrm{Mg \#} 74$ respectively. The compositions of these two phases, especially plagioclase, vary erratically in MCU IVa and are not in equilibrium with each other. $\mathrm{Sr}_{0}$ remains constant at about 0.7061 in the upper part of MCU IIIe and lowest $12 \mathrm{~m}$ of MCU IVa, after which it shows a very systematic decrease to 0.7048 at the top of MCU IVa.

The leucotroctolite at the base of MCU IVb contains olivine of $\mathrm{Fo}_{7} 4$ and plagioclase of $\mathrm{An}_{52.5}$. The olivine composition reaches $\mathrm{Fo}_{70}$ in the next sample, after which there is a regression to F073.5 through the remainder of MCU IVb. The Ca-poor pyroxene in MCU IVb replaces olivine and their compositions are clearly in equilibrium with each other. Above MCU IVb, cumulus Ca-poor pyroxenes become increasingly evolved with stratigraphic 
height through MCU IV (Figures 5 and 6A). Plagioclase shows a slightly erratic trend from $\mathrm{An}_{53}$ at the base of MCU IVb to more sodic compositions in the overlying zones (Figures 5 and 6A). After the systematic upward trend to lower values in the upper part of MCU IVa, $\mathrm{Sr}_{0}$ shows a gradual increase through $\mathrm{MCU}$ IVb, $\mathrm{c}$, and $\mathrm{d}$ (Figures 5 and 6A).

As will be discussed later, the compositional regression across the MCU III - IV boundary reflects a major addition of magma to the chamber. MCU IVa is interpreted as having formed by crystallization during the mixing of new, primitive magma and resident, evolved, contaminated magma.

Table 1 : Major-and trace-element analyses of selected fine-to medium-grained jotunites from the discordant northern margin of the Bierkreim-Sokndal Intrusion.

\begin{tabular}{|c|c|c|c|}
\hline \multicolumn{4}{|c|}{ Major-element data } \\
\hline Sample \# & B90 & B93 & B95 \\
\hline $\mathrm{SiO}_{2}$ & 49.8 & 50.6 & 48.8 \\
\hline $\mathrm{TiO}_{2}$ & 4.2 & 4.1 & 4.2 \\
\hline $\mathrm{A}_{2}{ }_{2} \mathrm{O}_{3}$ & 15.0 & 14.8 & 14.7 \\
\hline $\mathrm{Fe}_{2} \mathrm{O}_{3}$ & 1.1 & 1.5 & 1.9 \\
\hline $\mathrm{FeO}$ & 11.6 & 10.7 & 10.8 \\
\hline $\mathrm{MnO}$ & 0.2 & 0.2 & 0.2 \\
\hline $\mathrm{MgO}$ & 5.0 & 5.0 & 4.5 \\
\hline $\mathrm{CaO}$ & 6.7 & 6.3 & 6.8 \\
\hline $\mathrm{Na}_{2} \mathrm{O}$ & 2.4 & 2.5 & 2.5 \\
\hline $\mathrm{K}_{2} \mathrm{O}$ & 0.9 & 1.3 & 1.2 \\
\hline $\mathrm{p}_{2} \mathrm{O}_{5}$ & 0.8 & 0.7 & 1.1 \\
\hline LOI & 1.2 & 1.1 & 2.9 \\
\hline Total & 98.9 & 98.8 & 99.6 \\
\hline \multicolumn{4}{|c|}{ Trace-element (INAA, XRF and MS) data } \\
\hline \multicolumn{4}{|l|}{ ppm (XRF) } \\
\hline $\mathrm{S}$ & 1060 & 1390 & 1290 \\
\hline $\mathrm{V}$ & 237 & 245 & 248 \\
\hline $\mathrm{Cr}$ & 50 & 48 & 48 \\
\hline $\mathrm{Co}$ & 33 & 30 & 33 \\
\hline $\mathrm{Ni}$ & 56 & 56 & 53 \\
\hline $\mathrm{Cu}$ & 23 & 21 & 22 \\
\hline $\mathrm{Zn}$ & 133 & 114 & 133 \\
\hline $\mathrm{Y}$ & 36 & 28 & 36 \\
\hline $\mathrm{Zr}$ & 201 & 155 & 169 \\
\hline \multicolumn{4}{|l|}{ ppm (INAA) } \\
\hline La & 16.0 & 19.4 & 24.9 \\
\hline $\mathrm{Ce}$ & 39.5 & 46.9 & 61.0 \\
\hline $\mathrm{Nd}$ & 25.8 & 26.9 & 34.8 \\
\hline $\mathrm{Sm}$ & 8.0 & 7.0 & 9.7 \\
\hline $\mathrm{Eu}$ & 3.1 & 2.2 & 2.8 \\
\hline $\mathrm{Tb}$ & 1.5 & 1.1 & 1.1 \\
\hline Ho & & 1.0 & 1.1 \\
\hline $\mathrm{Tm}$ & 0.7 & 0.4 & n.d. \\
\hline $\mathrm{Yb}$ & 3.4 & 2.2 & 2.6 \\
\hline $\mathrm{Lu}$ & 0.5 & 0.4 & 0.5 \\
\hline \multicolumn{4}{|l|}{ ppm (MS) } \\
\hline $\mathrm{Rb}$ & 2.90 & 13.45 & 12.82 \\
\hline $\mathrm{Sr}$ & 446.67 & 439.95 & 432.70 \\
\hline $\mathrm{Nd}$ & 29.474 & 25.200 & 50.237 \\
\hline $\mathrm{Sm}$ & 7.204 & 5.326 & 11.232 \\
\hline${ }^{87} \mathrm{Sr} /{ }^{86} \mathrm{Sr}_{930}$ & 0.703021 & 0.708907 & 0.713724 \\
\hline${ }^{143} \mathrm{Nd} /{ }^{144} \mathrm{Nd}_{930}$ & 0.511355 & 0.511377 & 0.511454 \\
\hline
\end{tabular}

$\overline{\mathrm{XRF}}=\mathrm{X}$-ray fluorescence analysis. INAA = Instrumental neutron activation analysis. MS = Mass spectrometry. 


\section{MARGINAL JOTUNITES}

Fine- to medium-grained, granular rocks are present at several places along the steep, discordant northern margin of the BKSK and occur along the outer margin of a Marginal Zone of layered jotunite and norite that separate cumulates belonging to MCU IA and IB and quartzo-feldspathic gneiss of the envelope (Figure 1). The width of the Marginal Zone varies considerably. In places cumulates are in sharp contact with gneiss, while elsewhere there are up to $100 \mathrm{~m}$ of marginal rocks.

The outermost rocks of the Marginal Zone are generally sparsely to markedly porphyritic. Plagioclase phenocrysts are in places up to $2 \mathrm{~cm}$ in length and some exhibit skeletal overgrowths. The marginal rocks are generally massive, but where they have their thickest development their grain size increases inwards from the contact with the gneiss, plagioclase phenocrysts become more abundant and a layering defined by textural and modal variations appears. The layering is sub-parallel with the contact with the gneiss, but may be tortuous or corrugated on flat exposures. Along some contacts, the inner contact of the marginal rocks is gradational over $\sim 20 \mathrm{~m}$ into coarse-grained ilmenite leuconorite. These features suggest that the marginal rocks belong to a discontinuous Marginal Series and that the outermost granular rocks may be chilled representatives of the magma that was parental to the oldest part of the Layered Series.

The compositions of 3 samples of sparsely-porphyritic, fresh, marginal jotunite analysed by a variety of techniques, are reported in Table 1. These samples, from three different localities, have been selected as the most probable representatives of a parental magma whose composition has been least modified by assimilation of country rock gneiss. They have compositions similar to Ti-rich ferrobasalt and are characterized by high $\mathrm{FeO}_{\text {total }}$ (11.1-12.9 wt \%), $\mathrm{MgO}$ in a narrow range between 3.8 and 5.0 and low $\mathrm{CaO}$ (5.4-6.7 wt \%). They exhibit chondrite-normalized, rare-earth patterns with either a small positive (B90) or no Eu anomaly (B93 and B95), suggesting that previous fractionation or accumulation of plagioclase phenocrysts was very limited. The light REE-enriched patterns of B93 and B95 are almost identical, but sample B90 exhibits a lesser degree of lightREE enrichment, and generally lower REE concentrations. Their compositions are similar to jotunite between anorthosite xenoliths in the plagioclase cumulates of MCU IB (at Tjǿrn) that likewise has been claimed to be representative of a parental magma (Duchesne and Hertogen, 1988), and also to marginal jotunites of the Hidra Leuconorite (Duchesne et al., 1974).

A total of 7 samples of marginal jotunite have been analysed. They show a considerable variation in ${ }^{87} \mathrm{Sr}^{86} \mathrm{Sr}_{930}$ from 0.70302 to 0.71372 , corresponding to $\varepsilon \mathrm{Sr}_{930}$ of-5.6 to +146.4 respectively. $\varepsilon \mathrm{Nd}_{930}$ shows a more limited variation, from +0.3 to -2.7 . These isotopic compositions are similar to those of the jotunite dykes present in the region that exhibit $\mathrm{Sr}_{0}$ of $0.704-0.710$ and $\varepsilon \mathrm{Nd}_{930}$ in the range +5.4 to -1 (Duchesne, 1990).

\section{DISCUSSION}

\subsection{Fractionation trend, conditions of crystallization, and parental magma composition}

The Layered Series of the BKSK reflects crystallization in a periodically-replenished, continuously-fractionating magma chamber into which country rocks were being progressively assimilated. The sequence of crystallization represented by the megacyclic units in the BKSK suggests that they crystallized from a magma which initially had plagioclase \pm olivine on the liquidus, was sufficiently enriched in $\mathrm{TiO}_{2}$ for ilmenite to be an early crystallizing phase, and had a low $\mathrm{Ca}$ content in comparison with common basalts, as reflected by the delayed appearance of augite as a cumulus mineral and the relatively sodic cumulus plagioclase. The marginal jotunite has a composition consistent with these features of the Layered Series, supporting the hypothesis that they are representative of a parent magma that was compositionally similar to a Ti-rich ferrobasalt, but poor in augite components.

Anhydrous melting experiments using a fine-grained jotunite from the BKSK shows that such melts have plagioclase as the sole liquidus phase up to $\sim 7 \mathrm{~kb}$ at temperatures of $1150-1165^{\circ} \mathrm{C}$ and oxygen fugacities of between FMQ-2 and FMQ-4 (Vander Auwera and Longhi, 1994). Olivine, ilmenite and Ca-poor pyroxene (which crystallizes together with olivine) appear successively at lower temperatures. At higher pressure (7-13 $\mathrm{kb})$ plagioclase and Ca-poor pyroxene are the liquidus phases. These are joined by ilmenite $\sim 20^{\circ} \mathrm{C}$ below the liquidus and either olivine $\left(\sim \mathrm{Fo}_{60}\right)$ or $\mathrm{Ca}$-rich pyroxene at lower temperatures. Allowing for the low oxygen fugacity in the melting experiments, which stabilizes olivine relative to Ca-poor pyroxene and suppresses magnetite saturation, the crystallization sequence of the jotunite at moderate pressure is similar to that in the BKSK Layered Series. 
During much of the early evolution of the chamber the magma which flowed into the chamber generated thick sequences of plagioclase cumulates (leuconorite and minor anorthosite) found in MCUs IA and IB. Plagioclase was successively joined on the liquidus at lower temperatures by ilmenite, orthopyroxene, Ca-rich pyroxene, and magnetite. Magmas fed into the chamber during the later stages of its evolution, as represented by cumulates towards the bases of MCUs III and IV, crystallized plagioclase, olivine, ilmenite, and magnetite. At slightly lower temperature olivine was replaced by orthopyroxene and at the same time magnetite ceased crystallization. After a further temperature decrease magnetite resumed crystallization, and later, Ca-rich pyroxene and apatite became cumulus phases. MCU II appears to represent an intermediate stage in the evolution of the magma chamber in that the basal rocks are generally plagioclase-ilmenite-magnetite cumulates that are succeeded by plagioclase-orthopyroxene-ilmenite cumulates. Olivine is present only locally at the base of this unit.

The differences in the order of crystallization of cumulus minerals in the lower and upper MCUs may be due to changes in silica activity or oxygen fugacity in the magmas introduced, changes in pressure, or variations in the extent of mixing of inflowing and resident magmas.

Morse (1979a) has shown that silica activity and oxygen fugacity in magmas usually vary in concert, decreases in either would have increased the stability of olivine relative to orthopyroxene. Thus magmas which were emplaced into the chamber during the later stages of its evolution may have had slightly lower $\mathrm{a}_{\mathrm{SiO} 2}$ or $\mathrm{f}_{\mathrm{O} 2}$ than those that intruded earlier. Crystallization of introduced magmas under lower pressure would also favour olivine rather than orthopyroxene as a liquidus or near-liquidus phase. It can be envisaged that the pressure gradually decreased during the evolution of the BKSK magma chamber, due for instance to tectonic exhumation during crustal extension, causing the precipitation of olivine from magmas emplaced during the later stages.

The anomalous appearance of cumulus magnetite in the basal leucotroctolitic cumulates of the upper MCUs, its subsequent absence over significant stratigraphic intervals and later reappearance appears to be the result of ephemeral conditions related to the emplacement of new magma. It is noteworthy that cumulus magnetite exhibits this anomalous behaviour only in MCUs II, III, and IV, where the basal cumulates rest on lowertemperature, magnetite-bearingcumulates. The experiments on hybrids conducted by Sharpe and Irvine (1983), although involving the mixing of olivine boninite (with chromite alone as the liquidus phase) and aluminous tholeiite (with plagioclase as the liquidus phase) compositionally removed from the magmas involved in the BKSK, show the crystallization sequence plagioclase + olivine + spinel (presumed to be enriched in $\mathrm{FeO}_{2} \mathrm{Fe}_{2} \mathrm{O}_{3}$ ) and $\mathrm{TiO}_{2}$ ), plagioclase + orthopyroxene + olivine, plagioclase + orthopyroxene, similar to that observed in the lower parts of MCUs $\Pi$ I and IV. Magnetite in the leucotroctolites of the BKSK is believed to have been stabilized by the $\mathrm{Cr}$ content of new magma that flowed into the chamber and mixed with relatively small amounts of magnetite-saturated resident magma.

The scarcity of hydrous minerals in the BKSK, except in the most evolved rocks, suggests crystallization from relatively anhydrous magmas. This is supported by the occurrence of hypersolvus alkali feldspar and geothermometry based on coexisting igneous pyroxenes in the mangerite and quartz mangerite which gives $908 \pm 70^{\circ} \mathrm{C}$ and $839 \pm 70^{\circ} \mathrm{C}$ by the Wells (1977) and Wood and Banno (1973) methods respectively (Rietmeijer, 1979). Crystallization temperatures and oxygen fugacities calculated from the estimated compositions of isolated hemo-ilmenite and Ti-magnetite grains that have preserved their magmatic compositions vary from $900-975^{\circ} \mathrm{C}$ and $10^{-11} \mathrm{~atm}$. (slightly above the $\mathrm{Ni}-\mathrm{NiO}$ buffer) for cumulates in the upper magnetite-bearing part of MCU IV to $750-800^{\circ} \mathrm{C}$ and $10^{-16} \mathrm{~atm}$. (slightly below FMQ) for the mangerite (Duchesne, 1972). The ubiquitous occurrence of hemo-ilmenite in the less-evolved cumulates suggests oxygen fugacities of at least $10^{-11}$ atm. during the early crystallization history of the BKSK. According to Snyder et al. (1993), the crystallization of ilmenite prior to magnetite from basaltic magmas is favoured by low oxygen fugacities and that fractionation of ilmenite (and silicates) results in an increase in oxygen fugacities (due to extraction of FeO). They suggest that this may be a general feature of tholeiitic magmas. The experiments on which these conclusions are based were conducted at varying oxygen fugacities less than $\mathrm{FMQ}$, but have little relevance for the $\mathrm{T}-\mathrm{fO}_{2}$ evolution of the BKSK magmas since the synthesized ilmenite had a low hematite content.

Morse (1979b) has discussed how plagioclase fractionation is affected by augite saturation and showed that fractional crystallization of plagioclase alone leads to a slow rate of change in the anorthite content of residual liquids. He has suggested that the augite effect may be responsible for the limited range in feldspar compositions in augite-poor, massif-type anorthosites (Morse, 1982). The BKSK seems to be a natural example of these principles. Both the phase layering and the composition of marginal rocks suggest derivation of the cumulates from augite-poor magmas and cryptic variation in plagioclase composition is inconspicuous in the BKSK Layered Series until Ca-rich pyroxene joins the fractionating assemblage. In addition, the occurrence of fayalite $\left(\mathrm{Fo}_{4}\right)$ with plagioclase of around $\mathrm{An}_{12}$ shows that residual liquids were relatively Ca-rich due to a low effective 
distribution coefficient for $\mathrm{An}_{\text {plag }} / \mathrm{An}_{\text {liq }}$ (Morse, 1979). Recent experiments on a jotunite from the BKSK (near Tjørn, Duchesne and Hertogen, 1988) show that the distribution coefficient for liquidus plagioclase is inversely related to pressure (Vander Auwera and Longhi, 1992; Longhi et al., 1993). Crystallization of the BKSK at elevated pressure will therefore have promoted fractionation of relatively sodic plagioclase and enhanced the augite effect.

\subsection{Evidence for magma stratification and the mechanism of magma replenishment}

The unfolding of the synclinal structure of the BKSK intrusion to bring the layering to an approximately horizontal disposition results in a broad, saucer-shaped magma chamber. The breadth/thickness ratio of the Bjerkreim lobe of the magma chamber at the present erosion level is about 3:1 (lateral extent $\sim 24 \mathrm{~km}$, thickness $\sim 8 \mathrm{~km}$ ), but for each individual magma influx it would have been much greater. For example, when the final batch of magma began to crystallize MCU IVb, this ratio must have been about 8:1.

The magma in the BKSK chamber is believed to have been strongly compositionally stratified, at least by the time that MCU III was crystallizing. The repeated influx of relatively dense, hot, primitive magma along the floor successively elevated the more buoyant, cooler, evolved resident magma, giving rise to compositional stratification from the base up. Extensive roof melts (see section 12.3) were buoyant and remained at the top of the chamber, leading to stratification downwards from the roof.

The jotunitic magmas that periodically discharged into the BKSK chamber had densities estimated from the partial molar volumes of Lange and Carmi-chael (1987) and Toplis et al. (1994) of $\sim 2.74-2.77 \mathrm{~g} \mathrm{~cm}^{3}$ at $1150^{\circ} \mathrm{C}$ and $5 \mathrm{~kb}$, assuming 0.0-0.5\% $\mathrm{H}_{2} \mathrm{O}$ (Vander Auwera and Longhi, 1994). Fractional crystallization of plagioclase from such magmas must have increased the densities of residual liquids. Modelling of the density evolution shows, however, that extraction of plagioclase, ilmenite and orthopyroxene or olivine in reasonable proportions could eventually have led to a decrease in density.

The geometry of phase contacts between MCUs III and IV (Figure 3) was explained by Nielsen and Wilson (1991) by crystallization of compositionally-stratified magma against a saucer-shaped floor (Figure 7). Zone d of MCU III was crystallizing from the basal layer of the compositionally-stratified magma in the deepest, central parts of the chamber while at the same time MCU IIIe was crystallizing on the flanks from a less dense, more evolved magma layer (Figure 7A). The absence of MCU IIIe in the central part of the magma chamber is therefore explained by non-deposition; this model also accounts for the symmetrical disposition of this unit on both flanks of the saucer-shaped chamber. It was at the stage of magma chamber evolution illustrated in Figure 7 A that new magma entered the chamber to form MCU IV (Figure 7B).

The compositional reversal through MCU IVa (Figures 5 and 6) reflects crystallization during magma influx and mixing between new, primitive magma and residual, contaminated magma. At the lowest point of the saucershaped chamber, reversals in mineral chemistry and Sr-isotopes would take place simultaneously when the new magma entered the chamber. In Figure 6B, however, it is apparent that there is a reversal in mineral chemistry at the top of MCU IIIe, below a change in cumulus assemblage (from plagioclase-orthopyroxene-clinopyroxeneilmenite-magnetite-apatite cumulates to plagioclase \pm ilmenite \pm orthopyroxene cumulates) that defines the base of MCU Iva. The systematic isotopic regression sets in about half way through zone IVa. This can be explained by the location of the Storeknuten section of Figure 6 on the flank of the saucer-shaped magma chamber floor (Figures 3 and 7). Space for the new magma was made available by the roof being pushed upwards and the magma chamber expanding laterally. While the new, dense magma started to mix with the basal layer of the resident magma, the overlying magma layers were elevated.

In the Storeknuten profile on the flank of the saucer-shaped chamber, hybrid magma first reached the crystallization front after the residual magma column had passed by and produced the compositional reversal in mineral chemistry at the top of MCU IIIe. The first hybrid magma that reached the Storeknuten profile produced a change in cumulus assemblage but did not change the Sr-isotope ratio, indicating that the hybrid was dominated by residual magma. Incomplete mixing and/or kinetic effects resulted in the crystallization of plagioclase and orthopyroxene that were not in equilibrium with each other in the lower part of MCU IVa (Figure 6B). The start of the gradual decrease in $\mathrm{Sr}$ isotope ratios in Figure 6B reflects crystallization from hybrid magma with a systematically increasing proportion of new magma. Eventually the hybrid reached a composition with the lowest Sr isotope ratio (0.7049) in the entire Layered Series at the top of MCU IVa. This marks the cessation of magma influx after which the basal magma layer in the chamber crystallized the most primitive cumulates in BKSK - the leucotroctolites in MCU IVb. 
Figure 7. (facing page). Schematic illustration of the evolution of the Bjerkreim-Sokndal magma chamber during the time interval represented by zones IIId-IVf (Figure 2). The vertical scale is considerably exaggerated in these sketches. Based on Nielsen and Wilson (1991). A) Crystallization of the upper part of MCU III from a compositionally-zoned magma column. Zone IIId is crystallizing from the central, lowest part of the basinal floor while zone IIIe crystallizes towards the margins from more evolved and less dense magma. B) Emplacement of dense, more primitive magma as a fountain in which mixing produces hybrid magma. The magma column is elevated and higher-temperature magma migrates up the inwardly-sloping floor, producing the gradual compositional regression in zone IIIe. The decrease in initial Sr isotope ratio seen in zone IVa reflects an increasing proportion of new magma in the basal hybrid. The roof of the chamber is being lifted to accommodate the new magma. C) Hybrid magma nearly fills the basin on the floor of the magma chamber and crystallizes zone IVa, producing an almost horizontal floor. D) Zone IVb and subsequent zones crystallize over the entire floor of the chamber.

A
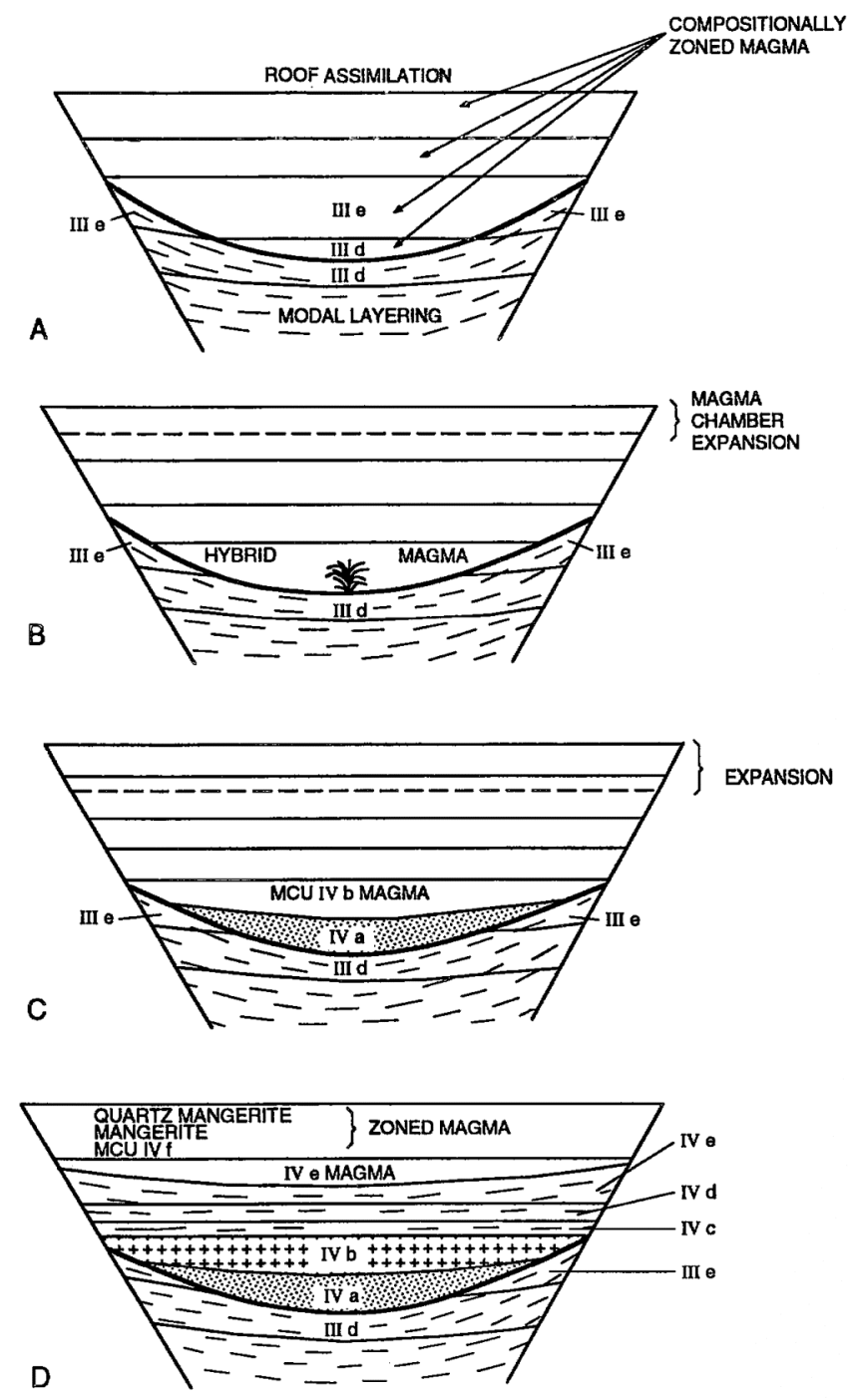

The fact that MCU IVa is thickest in the central, axial region of the magma chamber and wedges out towards the northern flank (Figures 3 and 7) is another result of the saucer-shaped form of the magma chamber floor. Magma 
influx and mixing took place in the lowest part of the chamber; the northern flank did not become flooded until the final stages of hybridization had been reached. The fact that the olivine-bearing unit MCU IVb has fairly constant thickness $(-100 \mathrm{~m})$ in the intrusion implies that the magma chamber floor was very close to horizontal during its crystallization; the hybrid magma producing MCU IVa must have filled in the central part of the saucer-form. If the floor was horizontal when MCU IVb started to crystallize, the lateral variation in thickness of MCU IVa can be used to estimate the slope of the floor. MCU IVa gradually wedges out from $90 \mathrm{~m}$ in profile D to between profiles $\mathrm{B}$ and $\mathrm{C}$ in Figure 3, a lateral distance of about $6 \mathrm{~km}$. This implies an apparent slope of about $2^{\circ}$ in the exposed section; the true slope must have been somewhat greater than this. Calculations based on geochemical modelling, the thickness of cumulate stratigraphy repeated, and $\mathrm{Sr}$ isotope ratios indicate that the new magma influx at the base of MCU IV had a thickness of 350-500 $\mathrm{m}$ in the Storeknuten section, and that MCU IVb represents about 20-30\% crystallization of this influx (Jensen et al., 1993).

Mixing of new and resident magmas probably took place in a turbulent fountain (Campbell and Turner, 1986) such that the proportion of new to residual magma in the hybrid gradually increased.

\subsection{Role of assimilation}

The remarkable sympathetic variation in the composition of cumulus minerals and $\mathrm{Sr}_{0}$ present in the BKSK cumulates (Figure 5) suggests that assimilation of country rocks was continuous during crystallization of the Layered Series. Furthermore, this relationship implies coupling of fractional crystallization and assimilation. In the BKSK the rate of fractional crystallization may have been governed by assimilation. The abundance of country-rock xenoliths preserved in parts of the Layered Series suggests that assimilation occurred as a result of the melting of blocks of gneiss derived from the roof of the chamber while they were being transported to the floor.

The role of assimilation in the BKSK magma chamber has been assessed quantitatively by Nielsen et al. (1996). They assumed that the parental magma had an $\mathrm{Sr}_{0}$ of 0.7049 (the lowest ratio measured in the Layered Series) and $600 \mathrm{ppm} \mathrm{Sr}$, whereas the contaminant had an $\mathrm{Sr}_{0}$ of 0.7196 and $160 \mathrm{ppm} \mathrm{Sr}$ (based on a charnockitic migmatite at $947 \pm 26 \mathrm{Ma}$, Versteeve, 1975). These end-member compositions give about $28 \%$ contamination by gneiss just before the final major magma influx, and $56 \%$ during the later stages of the life of the chamber as represented by the upper part of MCU IV the TZ, mangerite, and quartz mangerite. Assimilation of $>50 \%$ gneiss is improbable on a large scale and this result may cast doubt on the choice of the contaminant, which could have been more radiogenic than the average charnockitic migmatite. In a saucer-shaped magma chamber most of the heat will, however, be released through the roof. Buoyant, relatively low-temperature country rock melts can remain at the roof and be chemically decoupled from crystallization at the floor. Mixing of roof melts and liquids produced largely by fractional crystallization can have resulted in the high initial Sr ratios observed in rocks in the uppermost part of the BKSK.

\subsection{Origin of the Bjerkreim-Sokndal parental magmas}

The ultimate origin of the magmas parental to the BKSK, and the Rogaland jotunitic intrusions generally, is still unclear. It is apparent that they could not have been derived directly from the mantle, since they were saturated in plagioclase when emplaced into the crust. An alternative hypothesis is removal of olivine, aluminous pyroxene and possibly garnet from mantle-derived basalt at or close to the base of thickened continental crust. This is sufficient to explain the differentiated composition and the poverty in diopside and anorthite components. One of us favours the view that the parental magmas were generated by batch melting of noritic rocks in the lower crust (Duchesne, 1990), a model that is supported by the results of melting experiments on high-Al basalts (Baker and Eggler, 1987). In both of these hypotheses the composition of the ferrobasaltic liquids would have essentially been controlled by equilibrium with aluminous pyroxenes and possibly garnet, but not with plagioclase.

A major unresolved problem in modelling the origin of the parental magmas is the variable isotopic composition of the marginal jotunites of the BKSK. Interestingly, the Holocene Snake River Plain ferrobasalts that are compositionally similar to the Rogaland jotunites, have high ${ }^{87} \mathrm{Sr} /{ }^{86} \mathrm{Sr}$ and similar variations (Leeman et al., 1976), though they seem to be more systematically related to the degree of differentiation. Leeman et al. (1976) suggested that this may be due to selective contamination by small amounts of very radiogenic crustal materials, an ad hoc explanation that could also be applied to the BKSK, but that finds no support in the isotopic composition of the cumulates.

The nature of any relationship which may exist between the ferrobasalts parental to the BKSK, the monzonoritic 
minor intrusions and the anorthosite massifs also remains obscure. The lack of negative Eu anomalies in jotunite indicates that the ferrobasalts cannot be magmas residual after extensive plagioclase fractionation. One of us (J.C. Duchesne) has suggested that the ferrobasalt magmas may have resulted from partial melting of crustal rocks due to the thermal effects of the diapiric emplacement of the anorthosites. However, a more direct relationship is indicated by the jotunite chilled margin of the Hidra leuconorite and the thickness of leuconoritic cumulates present in the BKSK. The very aluminous pyroxene megacrysts suggest that the initial crystallization of the anorthosite massifs occurred at elevated pressures. However, the $\mathrm{Cr}$ contents (600-950 ppm) of the pyroxenes are difficult to reconcile with crystallization from ferrobasaltic magmas as represented by the jotunite, which generally contains $<50 \mathrm{ppm} \mathrm{Cr}$ (Duchesne et al, 1985 and Table 1), using generally accepted values for the partition coefficient. However, the distribution coefficient is very dependant on temperature and oxygen fugacity (Barnes, 1986). Recent experiments on a jotunite from the BKSK have shown a change in $\mathrm{DCr}^{\text {opx } / m e l t}$ with pressure from $<3$ at 1 atm to 14 at $10 \mathrm{~kb}$ (Vander Auwera et al., 1993).

\section{CONCLUSIONS}

The BKSK shows that members of the anorthosite kindred (andesine anorthosite, leuconorite, troctolite, norite, gabbronorite, mangerite, and quartz mangerite) can be generated by differentiation of Ti-rich, diopside-poor basic magmas with low Mg\# within crustal magma chambers. These rock types in the BKSK Layered Series were generated principally by fractional crystallization, accompanied by assimilation of roof gneisses, in a periodically-replenished magma chamber.

There is a record in the Layered Series of the BKSK of 6 major episodes of magma emplacement, each accompanied by lateral and upward enlargement of the chamber. At least two of these episodes were relatively persistent and were associated with mixing of new and lower-temperature resident magmas. Mixing resulted in hybrid magmas and is represented by mappable sequences of cumulates that exhibit regressive cryptic variations.

The generalized order of appearance of the main minerals during uninterrupted fractional crystallization at a late stage in the evolution of the magma chamber was plagioclase + olivine + he-rich ilmenite + Cr-bearing magnetite, orthopyroxene (- magnetite), Ti-poor magnetite, Ca-rich pyroxene + apatite, pigeonite, alkali feldspar, Fe-rich olivine, quartz. The earliest stages were characterized by the sequence plagioclase, he-rich ilmenite, orthopyroxene, Ca-rich pyroxene, Ti-poor magnetite. The latter order of crystallization is only fully developed in MCU IB; MCUs IA and II illustrate only the early part of the sequence. The differences are believed to be due to several causes. The earlier appearance of cumulus apatite and magnetite in the upper MCUs was probably due to entrainment into the inflowing magmas of the more-evolved magmas residing in the chamber that were already enriched in $\mathrm{P}_{2} \mathrm{O}_{5}$ and $\mathrm{Fe}_{2} \mathrm{O}_{3}$ due to previous fractional crystallization. The absence of cumulus olivine in the early history of the chamber may have been due to the emplacement of magmas with higher silica activities due to a higher degree of previous fractional crystallization at higher pressure, or an increased degree of mixing of inflowing and resident magmas.

The discordant geometry of phase contacts in the MCUs that results in the lateral wedging out of certain cumulus assemblages, is interpreted as due to the persistence of a vertical chemical zonation in the column of magma which existed in the chamber and the development of a basinal or half-basinal chamber floor.

The remarkable sympathetic variation of mineral chemistry and initial Sr ratios that exists in the upper part of the BKSK Layered Series suggests that assimilation of country rocks was continuous and that there also was a fairly constant relationship between rates of assimilation and fractional crystallization. Assimilation was probably promoted by the incorporation into the chamber of large numbers of xenoliths of gneiss from the roof.

\section{REFERENCES}

Baker, D.R., \& Eggler, D.H., 1987. Compositions of anhydrous and hydrous melts coexisting with plagioclase, augite and olivine or low-Ca pyroxene from 1 atm to $8 \mathrm{kbar}$ : Application to the Aleutian volcanic centre of Atka. Am. Miner. 72, 12-28.

Barnes, S.J., 1986. The distribution of chromium among orthopyroxene, spinel and silicate liquid at atmospheric pressure. Geochim.Cosmochim. Acta 50, 1889-909.

Campbell, I.H., \& Turner, J.S., 1986. The influence of viscosity on fountains in magma chambers. J.Petrology $21,1-30$ 
Demaiffe, D., Duchesne, J.C., \& Hertogen, J., 1979. Trace element variations and isotopic composition of charnockitic acidic rocks related to anorthosites (Rogaland, SW Norway). In Ahrens, L.H. (ed.) Origin and Distribution of the Elements. Pergamon Press, 417-29.

Demaiffe, D., \& Michot, J., 1985. Isotope geochronology of the Proterozoic crustal segment of southern Norway. In Tobi, A.C., \& Touret, J.L.R. (eds.) The Deep Proterozoic Crust in the North Atlantic Provinces. NATO ASI Ser. C 158, D. Reidel Publishing Co.: Dordrecht, 411-33.

Duchesne, J.C., 1970. Sur la provenance de xénolithes anorthositiques dans le massif de Bjerkreim-Sogndal (Norvège). Ann. Soc. Géol. Belg. 93, 643-56.

Duchesne, J.C., 1972. Iron-titanium oxide minerals in the Bjerkreim-Sogndal massif, South-western Norway. $J$. Petrology 13, 57-81. Duchesne, J.C., 1978. Quantitative modelling of Sr, Ca, Rb, and K in the BjerkreimSogndal Layered Lopolith (S.W. Norway). Contr. Miner. Petrol. 66, 175-84.

Duchesne, J.C., 1987. The Bjerkreim-Sokndal massif. In Maijer, C, \& Padget, P. (eds.) The geology of Southernmost Norway. Norges geol. unders. Spec. Pub. 1, 56-9.

Duchesne, J.C., 1990. Origin and evolution of monzonorites related to anorthosites. Schweiz. Mineral. Petrogr. Mitt. 70, 189-98.

Duchesne, J.C., \& Hertogen, J., 1988. Le magma parental du lopolithe de Bjerkreim-Sokndal (Norvège méridionale). C.R. Acad. Sci. Paris 90,45-48.

Duchesne, J.C., \& Maquil, R., 1987. The Egersund-Oga massif. In Maijer C, \& Padget P (eds.) The geology of Southernmost Norway. Norges geol. unders. Spec. Pub. 1, 50-6.

Duchesne, J.C., \& Michot, J., 1987. The Rogaland intrusive masses: Introduction. In Maijer C, \& Padget P (eds.) The geology of Southernmost Norway. Norges geol. unders. Spec. Pub. 1, 48-50.

Duchesne, J.C., Denoiseux, B., \& Hertogen, J., 1987. The norite-mangerite relationships in the BjerkreimSokndal layered lopolith (S.W. Norway). Lithos 20, 1-17.

Duchesne, J.C., Roelandts, I., Demaiffe, D., Hertogen, J., Gijbels, R., \& De Winter, J., 1974. Rare-earth data on monzonoritic rocks related to anorthosites and their bearing on the nature of the parental magma of the anorthositic series. Earth Planet Sci. Lett. 24, 325-35.

Duchesne, J.C., Roelandts, I., Demaiffe, D., \& Weis, D., 1985. Petrogenesis of monzonoritic dykes in the Egersund-Ogna anorthosite (Rogaland, S.W. Norway): trace elements and isotopic ( $\mathrm{Sr}, \mathrm{Pb}$ ) constraints. Contr. Miner. Petrol. 90, 214-25.

Duchesne, J.C., Wilmart, E., Demaiffe, D., \& Hertogen, J., 1989. Monzonorites from Rogaland (Southwest Norway): a series of rocks coeval but not comagmatic with massif-type anorthosites. Precamb.Res. 7, 111-28.

Duchesne, J.C., Schärer, U., \& Wilmart, E. 1993. A 10 Ma period of emplacement for the Rogaland anorthosites, Norway: evidence from U-Pb ages. Terra Nova 5, 64.

Glazner, A.F., 1994. Foundering of mafic plutons and density stratification of continental crust. Geology 22, 435-8.

Hermans, G.A.E., Tobi, A.C., Poorter, P.E., \& Maijer, C, 1975. The high-grade metamorphic Precambrian of the Sirdal-Ǿrsdal area, Rogaland/Vest-Agder, SW Norway. Norges geol. unders. 318,51-74.

Holdam, H.K., 1990. Bjerkreim-Sokndal intrusjonen, Sydnorge: En undersógelse af den nordostlige flankes petrologi og mineralkemi. Unpubl. Cand. scient. thesis, Univ. of Aarhus, Denmark.

Jansen, J.B.H., Blok, R.J.P., Bos, A., \& Scheelings, M., 1985. Geothermometry and geobarometry in Rogaland and preliminary results from the Bamble area, S. Norway. In Tobi, A.C., \& Touret, J.L.R. (eds.) The Deep Proterozoic Crust in the North Atlantic Provinces. NATO ASI Ser. C 158, D. Reidel Publishing Co.: Dordrecht, 499-516. 
Jensen, J.C., Nielsen, F.M., Duchesne, J.C., Demaiffe, D., \& Wilson, J.R., 1993. Magma influx and mixing in the Bjerkreim-Sokndal layered intrusion, South Norway: evidence from the boundary between two macrocyclic units at Storeknuten. Lithos 29, 311-25.

Krause, H., Gierth, E., \& Schott, W., 1985. Ti-Fe deposits in the South Rogaland igneous complex with special reference to the Ána-Sira anorthosite massif. Norges geol. unders. Bull. 402, 25-37.

Lange, R.A., \& Carmichael, I.S.E., 1987. Densities of $\mathrm{Na}_{2} \mathrm{O}-\mathrm{K}_{2} \mathrm{O}-\mathrm{CaO}-\mathrm{MgO}-\mathrm{FeO}-\mathrm{Fe}_{2} \mathrm{O}_{3}-\mathrm{Al}_{2} \mathrm{O}_{3}-\mathrm{SiO}_{2}$ liquids: New measurements and derived partial molar volumes. Geochim. Cosmochim. Acta 51, 2931-46.

Leeman, W.P., Vitaliano, C.J., \& Prinz, M., 1976. Evolved lavas from the Snake River Plain: Craters of the Moon National Momument, Idaho. Contr. Miner. Petrol. 56, 35-60.

Longhi, J., Fram, M.S., Vander Auwera, J., \& Montieth, J.N., 1993. Pressure effects, kinetics, and reology of anorthositic and related magmas. Am. Miner. 78, 1016-30.

Maijer, C, 1987. The metamorphic envelope of the Rogaland intrusive complex. In Maijer, C, \& Padget, P. (eds.) The geology of Southernmost Norway. Norges geol. unders. Spec. Pub. 1, 68-73.

Michot, J., 1961. The anorthositic complex of Haaland-Helleren. Norsk geol. Tidsskrift 41, 157-72.

Michot, J., \& Michot, P., 1970. The problem of the anorthosites. The South Rogaland igneous complex (South Western Norway). In: Isachsen, Y.W. (ed.) Origin of anorthosites and related rocks. New York State Mus. Sci. Ser. Mem. 18, 399-410.

Michot, P., 1960. La géologie de la catazone: le problème des anorthosites, la palingenèse basique et la tectonique catazonale dans le Rogaland meridionale (Norvege meridionale). Norges geol. unders. 212, 1-54.

Michot, P., 1965. Le magma plagioclasique. Geol. Rundschau 54, 956-76.

Morse, S.A., 1979a. Reaction constants for En-Fo-Sil equilibria: An adjustment and some applications. Am. J. Sci. 279, 1060-9.

Morse, S.A., 1979b. Influence of augite on plagioclase fractionation. J. Geol. 87, 202-8.

Nielsen, F.M., \& Wilson, J.R., 1991. Crystallization processes in the Bjerkreim-Sokndal layered intrusion, south Norway: evidence from the boundary between two macrcyclic units. Contr. Miner. Petrol. 107, 403-14.

Nielsen, F.M., Campbell, I.H., McCulloch, M., \& Wilson, J.R. (1996). A strontium isotopic investigation of the Bjerkreim-Sokndal layered intrusion, southwest Norway. J. Petrology 37, 171- 94.

Paludan, J., Hansen, U.B., \& Olesen, N.Ǿ. (1994). Structural evolution of the Precambrian Bjerkreim-Sokndal Intrusion, South Norway. Norsk geol. Tidsskrift. 74, 185-98.

Pasteels, P., Michot, J., \& Lavreau, J., 1970. Le complexe éruptiv du Rogaland méridional (Norvège).Signification pétrogénétique de la farsundite et de la mangérite quartzique des unités orientales: arguments géochronologiques et isotopiques. Ann. Soc. Géol. Belg. 93, 453-76.

Pasteels, P., Demaiffe, D., \& Michot, J., 1979. U-Pb and Rb-Sr geochronology of the eastern part of the South Rogaland igneous complex. Lithos 12, 199-208.

Poorter, R.P.E., 1972. Palaeomagnetism of the Rogaland Precambrian (Southwestern Norway). Phys. Earth Planet. Interiors 5, 167-76.

Rietmeijer, F.J.M., 1979. Pyroxenes from iron-rich igneous rocks in Rogaland, S.W. Norway. Geol. Ultraiectina $21,341 \mathrm{pp}$.

Rietmeijer, F.J.M., 1984. Pyroxene (re-)equilibration in the Precambrian terrain of SW Norway between 1030990 and reinterpretation of events during regional cooling. Norsk geol. Tidsskrift 64, 7-20. 
Roelandts, I., \& Duchesne, J.C., 1979. Rare-earth elements in apatite from layered norites and iron-titanium oxide ore bodies related to anorthosites (Rogaland, S.W. Norway). In Ahrens, L.H. (ed.) Origin and Distribution of the Elements. Pergamon Press, 199-212.

Schiellerup, H., 1991. Bjerkreim-Sokndal intrusjonen. En petrologisk, mineral- og geokjemisk undersegelse af Bjerkreimloben i omrădet omkring Helleland. Unpubl. Cand. scient. thesis, Univ. of Aarhus, Denmark.

Schärer, U., Wilmart, E., \& Duchesne, J.C., 1992. U-Pb age constraints on the emplacement of Rogaland anorthosites. Abstract, IGCP 2901992 meeting, Rogaland, Norway.

Sharpe, M.R., \& Irvine, T.N., 1983. Melting realtions of two Bushveld chilled margin rocks and implications for the origin of chromitite. Carnegie Inst. Yrbk. 82, 295-300.

Smithson, S.B., \& Ramberg, I.B., 1979. Gravity interpretation of the Egersund anorthosite complex, Norway: Its petrological and geothermal significance. Geol. Soc. Am. Bull. 90, 199-204.

Snyder, D., Carmichael, I.S.E., \& Wiebe, R.A., 1993. Experimental study of liquid evolution in an Ferich, layered mafic intrusion: constraints of Fe-Ti oxide precipitation on the $\mathrm{T}_{-} \mathrm{fO}_{2}$ and $\mathrm{T}-\mathrm{p}$ paths of tholeiitic magmas. Contr. Miner. Petrol. 113, 73-86.

Sundvoll, B., 1987. The age of the Egersund dyke swarm SW Norway: Some tectonic implications. Terra Cognita 7, 180.

Tobi, A.C., Hermans, G.A.E.M., Maijer, C, \& Jansen, J.B.H., 1985. Metamorphic zoning in the high-grade Proterozoic of Rogaland - Vest Agder, SW Norway. In Tobi, A.C, \& Touret, J.L.R. (eds.) The Deep Proterozoic Crust in the North Atlantic Provinces. NATO ASI Ser. C 158, D. Reidel Publishing Co., Dordrecht, 477-97.

Toplis, M.J., Libourel, G., \& Carroll, M.R., 1994. The role of phosphorus in crystallisation processes of basalts: An experimental study. Geochim. Cosmochim. Ada 58, 797-810.

Vander Auwera, J., \& Longhi, J., 1992. Phase equilibria and fractionation paths from 1 atm up to $16 \mathrm{~Kb}$ of the monzonoritic Tjǿrn chilled facies: Implications for the Bjerkreim-Sokndal Lopolith (Southern Norway). Abstract IGCP 290 Origin ofanorthosites, Moi meeting 1992.

Vander Auwera, J., Longhi, J., \& Duchesne, J.C., 1993. Jotunites from the Rogaland Province (Norway): constraints from experimental data and the partitioning of $\mathrm{Sr}$ (plag/melt) and $\mathrm{Cr}$ (opx/melt). EOS 74, 659.

Vander Auwera, J., \& Longhi, J. (1994). Experimental study of a jotunite (hypersthene monzodiorite): constraints on the parent magma composition and crystallisation conditions $\left(\mathrm{P}, \mathrm{T}, \mathrm{fO}_{2}\right)$ of the Bjerkreim-Sokndal layered intrusion (Norway). Contr. Miner. Petrol 118, 60-78.

Versteeve, A.J., 1975. Isotope geochronology in the high-grade metamorphic Precambrian of southwestern Norway. Norges geol. unders. 318, 1-50.

Wells, P.R.A., 1977. Pyroxene thermometry in simple and complex systems. Contr. Miner. Petrol. 62, 129-39.

Wiebe, R.A., 1984. Co-mingling of magmas in the Bjerkreim-Sogndal lopolith (S.W. Norway): evidence for the composition of residual liquids. Lithos 17, 171-88.

Wielens, J.B.W., Andriessen, P.A.M., Boelrijk, N.A.I.M., Hebeda, E.H., Priem, H.N.A., Verdurmen, E.A.T., \& Verschure, R.H., 1980. Isotope geochronology in the high-grade metamorphic Precambrian of southwestern Norway: New data and interpretations. Norges geol. unders. 359, 1- 30.

Wilmart, E., \& Duchesne, J.C., 1987. Geothermobarometry of igneous and metamorphic rocks around the ÁnaSira anorthosite massif: Implications for the depth of emplacement of the South Norwegian anorthosites. Norsk geologist Tidsskrift 67, 185-96.

Wilmart, E., Demaiffe, D., \& Duchesne, J.C., 1989. Geochemical constraints on the genesis of the Tellnes ilmenite deposit, Southwest Norway. Econ. Geol. 84, 1047-56. 
Published in : Layered intrusions (1996) R.G. Cawthorn, ed., Elsevier, Amsterdam, pp. 231-255

Status : Postprint (Author's version)

Wood, B., \& Banno, S., 1973. Garnet-orthopyroxene and orthopyroxene-clinopyroxene relationships in simple and complex systems. Contr. Miner. Petrol. 42, 109-24. 